OPEN ACCESS

Edited by:

Francesca Chiodi,

Karolinska Institutet (KI), Sweden

Reviewed by:

Anna Nilsson,

Karolinska Institutet (KI), Sweden Anne-Sophie Beignon,

Centre National de la Recherche Scientifique (CNRS), France

*Correspondence:

Rita Carsetti

rita.carsetti@opbg.net

${ }^{\dagger}$ These authors have contributed equally to this work

Specialty section: This article was submitted to

Viral Immunology,

a section of the journal

Frontiers in Immunology

Received: 28 September 2020 Accepted: 20 November 2020 Published: 16 December 2020

Citation

Carsetti R, Zaffina S, Piano Mortari E,

Terreri S, Corrente F, Capponi C,

Palomba P, Mirabella M, Cascioli S,

Palange $P$, Cuccaro I, Milito $C$,

Zumla A, Maeurer M, Camisa V.

Vinci MR, Santoro A, Cimini E,

Marchioni L, Nicastri E, Palmieri F

Agrati C, Ippolito G, Porzio O,

Concato C, Onetti Muda A, Raponi M, Quintarelli C, Quinti I and Locatelli F (2020) Different Innate and Adaptive

Immune Responses to SARS-CoV-2 Infection of Asymptomatic,

Mild, and Severe Cases.

Front. Immunol. 11:610300. doi: 10.3389/fimmu.2020.610300

\section{Different Innate and Adaptive Immune Responses to SARS-CoV-2 Infection of Asymptomatic, Mild, and Severe Cases}

Rita Carsetti ${ }^{1,2 *}$, Salvatore Zaffina ${ }^{3,4}$, Eva Piano Mortari ${ }^{1 \dagger}$, Sara Terreri ${ }^{1 \dagger}$, Francesco Corrente ${ }^{2}$, Claudia Capponi ${ }^{2}$, Patrizia Palomba ${ }^{2}$, Mattia Mirabella $^{2}$, Simona Cascioli ${ }^{5}$, Paolo Palange ${ }^{6}$, Ilaria Cuccaro ${ }^{6}$, Cinzia Milito ${ }^{7}$, Alimuddin Zumla ${ }^{8,9}$, Markus Maeurer ${ }^{10,11}$, Vincenzo Camisa ${ }^{3,4}$, Maria Rosaria Vinci ${ }^{3,4}$, Annapaola Santoro ${ }^{3,4}$, Eleonora Cimini ${ }^{12}$, Luisa Marchioni ${ }^{13}$, Emanuele Nicastri ${ }^{13}$, Fabrizio Palmieri ${ }^{13}$, Chiara Agrati $^{12}$, Giuseppe Ippolito ${ }^{14}$, Ottavia Porzio ${ }^{15,16}$, Carlo Concato ${ }^{17}$, Andrea Onetti Muda ${ }^{18}$, Massimiliano Raponi ${ }^{4}$, Concetta Quintarelli ${ }^{19,20}$, Isabella Quinti ${ }^{7}$ and Franco Locatelli ${ }^{19,21}$

\footnotetext{
${ }^{1}$ B Cell Pathophysiology Unit, Immunology Research Area, Bambino Gesù Children's Hospital Istituto di Ricovero e Cura a Carattere Scientifico (IRCSS), Rome, Italy, ${ }^{2}$ Diagnostic Immunology Unit, Department of Laboratories, Bambino Gesù Children's Hospital, IRCCS, Rome, Italy, ${ }^{3}$ Occupational Medicine/Health Technology Assessment and Safety Research Unit, Clinical-Technological Innovations Research Area, Bambino Gesù Children's Hospital, IRCSS, Rome, Italy, ${ }^{4}$ Health Directorate, Bambino Gesù Children's Hospital, Istituto di Ricovero e Cura a Carattere Scientifico, Rome, Italy, ${ }^{5}$ Research Laboratories, Bambino Gesù Children's Hospital, IRCCS, Rome, Italy, ${ }^{6}$ Department of Public Health and Infectious Diseases Pulmonary Division, Policlinico Umberto I Hospital, Rome, Italy, ${ }^{7}$ Department of Molecular Medicine, Sapienza University of Rome, Rome, Italy, ${ }^{8}$ Center for Clinical Microbiology, Division of Infection and Immunity, University College London, London, United Kingdom, ${ }^{9}$ NIHR Biomedical Research Centre, UCL Hospitals NHS Foundation Trust, London, United Kingdom, 10 Immunotherapy Programme, Champalimaud Foundation, Lisbon, Portugal, ${ }^{11}$ Med Clinic, University of Mainz, Mainz, Germany, ${ }^{12}$ Cellular Immunology Laboratory, INMI L Spallanzani, IRCCS, Rome, Italy, ${ }^{13}$ Clinical Department, INMI L Spallanzani, IRCCS, Rome, Italy, ${ }^{14}$ Scientific Direction, INMI L Spallanzani, IRCCS, Rome, Italy, ${ }^{15}$ Medical Laboratory Unit, Bambino Gesù Children's Hospital, IRCCS, Rome, Italy, ${ }^{16}$ Department of Experimental Medicine, University of Rome Tor Vergata, Rome, Italy, ${ }^{17}$ Virology Unit, Bambino Gesù Children's Hospital, IRCCS, Rome, Italy, ${ }^{18}$ Department of Laboratories, Bambino Gesù Children's Hospital, Rome, Italy, ${ }^{19}$ Department of Hematology/Oncology, Bambino Gesù Children's Hospital, IRCCS, Rome, Italy, ${ }^{20}$ Department of Clinical Medicine and Surgery, University of Naples Federico II, Naples, Italy, ${ }^{21}$ Department of Pediatrics, Sapienza, University of Rome, Rome, Italy
}

SARS-CoV-2 is a novel coronavirus, not encountered before by humans. The wide spectrum of clinical expression of SARS-CoV-2 illness suggests that individual immune responses to SARS-CoV-2 play a crucial role in determining the clinical course after first infection. Immunological studies have focused on patients with moderate to severe disease, demonstrating excessive inflammation in tissues and organ damage. In order to understand the basis of the protective immune response in COVID-19, we performed a longitudinal follow-up, flow-cytometric and serological analysis of innate and adaptive immunity in $\mathbf{6 4}$ adults with a spectrum of clinical presentations: $\mathbf{2 8}$ healthy SARS-CoV-2negative contacts of COVID-19 cases; 20 asymptomatic SARS-CoV-2-infected cases; eight patients with Mild COVID-19 disease and eight cases of Severe COVID-19 disease. Our data show that high frequency of NK cells and early and transient increase of specific IgA, IgM and, to a lower extent, IgG are associated with asymptomatic SARS-CoV-2 
infection. By contrast, monocyte expansion and high and persistent levels of $\lg A$ and $\lg G$, produced relatively late in the course of the infection, characterize severe disease. Modest increase of monocytes and different kinetics of antibodies are detected in mild COVID-19. The importance of innate NK cells and the short-lived antibody response of asymptomatic individuals and patients with mild disease suggest that only severe COVID-19 may result in protective memory established by the adaptive immune response.

Keywords: SARS-CoV-2, COVID-19, innate and adaptiveimmune response, B cells, NK cell, monocytes, antibodies

\section{INTRODUCTION}

SARS-CoV-2 is a novel coronavirus, not encountered before by humans. Thus, everyone is susceptible to infection as the SARSCoV-2 virus rapidly spreads in the current Coronavirus disease 2019 (COVID-19) pandemic. A wide spectrum of clinical expression of SARS-CoV-2 infection occurs, ranging from asymptomatic to mild upper respiratory tract illness, or moderate to severe disease with respiratory distress and multi-organ failure requiring intensive care and organ support (1). This variability of disease severity suggests that the individual immune responses to SARS-CoV-2 play a crucial role in determining the clinical course after first infection. Understanding the pathogenesis of COVID-19 disease requires in-depth study of underlying immune responses (2). This includes the cellular and molecular basis of the successful protective mechanisms and the role of dysregulated and excessive inflammation $(3,4)$. During the 2003 SARS outbreak, the efficacy of the innate immune responses to SARS-CoV-1 appeared to determine the extent of virus load (5) and adaptive immunity played a critical role during the later stages of infection (6).

In COVID-19, lymphopenia is common and correlates with severity of clinical disease similarly to severe influenza and other respiratory viral infections (7-9). Because of lymphopenia, neutrophil-lymphocyte ratio (NLR) and monocyte-lymphocyte ratio (MLR) increase in patients affected by severe COVID-19 $(10,11)$. Lymphopenia is caused by the reduction of both $\mathrm{CD}^{+}$ and $\mathrm{CD} 8^{+} \mathrm{T}$ cells. Surviving T cells are functionally exhausted, and reduced T-cell count predicts an unfavorable clinical course $(12,13)$. $\mathrm{T}$ cells able to react to SARS-CoV-2 peptides can be demonstrated in healthy individuals, partly because of cross-reactivity with previous infections by other coronaviruses (14) and are expanded in individuals convalescent from COVID-19 (15).

Antibodies to SARS-CoV-2 are produced in large amounts in patients with severe disease, two-three weeks after the occurrence of first symptoms (16). The role of antibodies in viral elimination is supported by the successful use of convalescent plasma in patients with severe COVID-19 (17). Neutralizing antibodies are directed against the Receptor Binding Domain (RBD) or to other regions contained in the S1 subunit of the Spike protein (18-20). While immune responses to novel antigens encountered for the first time, are first dominated by antibodies of IgM isotype, followed by IgG $(21,22)$, the kinetics and protective or deleterious nature of the antibody responses to SARS-CoV-2 remains to be defined. Initial studies suggest that IgG may be produced earlier or at the same time with $\operatorname{IgM}(16,23,24)$. A recent study indicated that the $\operatorname{IgA}$ response to SARS-CoV-2 may be rapid, strong, and persistent $(25,26)$. The observation that the highest antibody levels are found in patients with severe COVID-19 disease led to the suggestion that antibodies to SARS-CoV-2 may be damaging or ineffective rather than protective (27-29), as was reported from very sick patients with Middle East respiratory syndrome (MERS) (30).

In order to identify the immunological features associated with the different clinical forms of SARS-CoV-2 infection, we performed a longitudinal study by standard 7-9 color flowcytometry comparing innate and adaptive immune populations of adults with asymptomatic SARS-CoV-2 infection, mild and severe COVID-19 disease and healthy SARS-CoV-2 negative contacts. We also measured levels and kinetics of IgG, IgA, and IgM anti-SARS-CoV-2 antibodies in the serum.

\section{MATERIALS AND METHODS}

\section{Study Design}

Patients were enrolled in in-patient and out-patient settings if they agreed to participate and fulfilled the inclusion/exclusion criteria. Sixty-four adult patients were enrolled in the study (Supplementary Table S1A). At enrollment, after the protocol procedures (including medical history, physical examination, laboratory examination) participants were assigned to the study group: a) Contacts of SARS-CoV-2 confirmed cases who were negative by qPCR and were included as control group (28 patients); b) Asymptomatic cases (20 patients) tested positive for viral RNA and had no symptoms. Asymptomatic patients were quarantined and monitored for 14 days, and quarantine ended when two consecutive nasopharyngeal swabs showed negative results; c) Mild COVID-19 disease (eight patients), defined by positive SARS-CoV-2 nasopharyngeal swab qPCR test, with symptoms such as fever, myalgia, and fatigue without obvious chest HRCT findings for COVID-19, did not require hospitalization; d) Severe COVID-19 disease (eight patients) with clinical signs of pneumonia (fever, cough, dyspnoea, fast breathing) plus one of the following: respiratory rate $>30$ breaths/min; severe respiratory distress; or $\mathrm{SpO} 2<90 \%$ on room air. Additional 77 patients with severe COVID-19 were recruited from the INMI, Lazzaro Spallanzani (34 ICU and 43 non-ICU, Supplementary Table S1B). Patients were admitted to 
ICU if they had pneumonia or new or worsening respiratory symptoms with chest imaging showing bilateral opacities, not fully explained by volume overload, lobar or lung collapse, or nodules with a oxygenation impairment:

- Mild ARDS: $200 \mathrm{mmHg}<\mathrm{PaO} 2 / \mathrm{FiO} 2 \mathrm{a} \leq 300 \mathrm{mmHg}$ (with PEEP or CPAP $\geq 5 \mathrm{cmH} 2 \mathrm{O}$ ).

- Moderate ARDS: $100 \mathrm{mmHg}<\mathrm{PaO} 2 / \mathrm{FiO} 2 \leq 200 \mathrm{mmHg}$ (with PEEP $\geq 5 \mathrm{cmH} 2 \mathrm{O})$.b

- Severe ARDS: $\mathrm{PaO} 2 / \mathrm{FiO} 2 \leq 100 \mathrm{mmHg}$ (with PEEP $\geq 5$ cmH2O) (31).

Contacts, asymptomatic individuals and patients with mild disease were Health Care Workers (HCW) of the Bambino Gesù Children Hospital. We included in the study all HCWs that had a positive swab in the period between March 15 and May 31, 2020 and their contacts (who had a negative swab). Blood and serum samples were collected at weekly intervals since diagnosis (first positive nasopharyngeal swab). Severe cases were patients from the Pulmonary division of the Department of Public Health and infectious diseases, Policlinico Umberto I Hospital, Rome, Italy.

\section{Ethical Approval}

Ethical approval was obtained from the Medical Research and Ethics Committee at Sapienza, University of Rome and from the Ethics Committee at INMI, Lazzaro Spallanzani. According to the guidelines on Italian observational studies as established by the Italian legislation about the obligatory occupational surveillance and privacy management; HCWs' confidentiality was safeguarded, and informed consent was obtained from all the participants. The study was performed in accordance with the Good Clinical Practice guidelines, the International Conference on Harmonization guidelines, and the most recent version of the Declaration of Helsinki.

\section{Flow-Cytometry and Antibodies}

Four leukocyte profiling panels computing seven- to nine-surface marker antigens for monitoring the major leukocyte subsets as well as characteristics of T cell, B cell, monocytes and NK cells subsets were designed (Supplementary Table S2). Results of immuneprofile of analyzed patients are reported in Supplementary Tables S3-10. The graphs of the single time points refer to the sample obtained immediately after the first positive nasopharyngeal swab. When available, we also show the results obtained at different time points.

$1 \mathrm{ml}$ of total blood (EDTA) was incubated with the lysing solution Pharm Lyse (BD) to lyse red blood cells. Then, cells were divided in four equal aliquots and stained with the appropriate combination of fluorochrome-conjugated antibodies (Supplementary Table S2) to identify immune cell subsets according to standard techniques. For the staining of Supplementary Figure S7, heparinized blood of three healthy donors was isolated by Ficoll Paque ${ }^{\mathrm{TM}}$ Plus 206 (Amersham Pharmacia Biotech) density-gradient centrifugation. Peripheral blood mononuclear cells (PBMCs) were then stained with antibodies against CD19, CD24, CD27, CD38, IgM, IgG, IgA, and IgD (Supplementary Table S2). Cells were acquired on a BD FACSLyric $^{\mathrm{TM}}$ (BD Biosciences). Data were analyzed with FlowJo ver. 10 (Treestar). Dead cells were excluded from analysis by side/ forward scatter gating.

\section{Serum Samples}

Included in this study were 160 serum samples obtained from subjects with available clinical records. In particular: fifty-one sera from SARS-CoV-2 negative contacts, sixty-three from SARS-CoV2 asymptomatic patients, thirty-one from COVID-19 mild patients, and fifteen from COVID-19 severe patients. 86 samples from 28 patients were collected at different time points. All sera were kept on ice after collection and then stored at $-80^{\circ} \mathrm{C}$.

\section{Serological Assays}

The Euroimmun Anti-SARS-CoV-2 ELISA IgG and IgA assays (Euroimmun), were performed on serum samples according to the manufacturer's instructions. The recommended serum sample dilutions used were 1:100; in samples in which the IgA or IgG quantity was not detectable (overflow), we used $1: 1,000,1: 3,000,1: 6,000,1: 25,000$ dilutions. Values were then normalized for comparison. These ELISA assays provide a semiquantitative in vitro determination of human antibodies of the immunoglobulin classes IgG and IgA against the SARS-CoV-2. The microplate wells are coated with recombinant S1 structural protein. The results were evaluated by calculation of the ratio between the extinction of samples and the extinction of the calibrator. The ratio interpretation was as follows: $<0.8=$ negative, $\geq 0.8$ to $<1.1$ = borderline, $\geq 1.1$ = positive.

For the detection of IgM anti RBD we developed an in-house ELISA. 96-well plates (Corning) were coated overnight with 1 $\mu \mathrm{g} / \mathrm{ml}$ of purified SARS-CoV-2 RBD protein (Sino Biological). After washing with PBS/0.05\% Tween and blocking with PBS/1\% $\mathrm{BSA}$, plates were incubated for $1 \mathrm{~h}$ at $37^{\circ} \mathrm{C}$ with diluted sera. Serum samples were measured at 1:100 dilutions. After washing, plates were incubated for $1 \mathrm{~h}$ at $37^{\circ} \mathrm{C}$ with peroxidase-conjugated goat anti-human IgM antibody (Jackons ImmunoResearch Laboratories). The assay was developed with $o$-phenylendiamine tablets (Sigma-Aldrich) as a chromogen substrate. Absorbance at $450 \mathrm{~nm}$ was measured, and IgM concentrations were calculated by interpolation from the standard curve based on serial dilutions of monoclonal human IgM antibody against SARS-CoV-2 Spike-RBD (Invivogen). Due to the unavailability of a human IgM antibody against SARS-CoV-2 S1 to be used as standard we were unable to quantify the level of anti-S1 IgM. We could, however compare the OD measured in plates coated with either RBD or S1 (data not shown).

\section{Statistical Analysis}

For the comparison of more than two independent groups, the non-parametric Kruskal-Wallis test was used, and if significant, pairwise comparisons were evaluated by the MannWhitney $U$-test. P values less than 0.05 were considered statistically significant. 


\section{RESULTS}

\section{Clinical Characteristics}

SARS-CoV-2 asymptomatic patients (20 patients, M/F 4/16, mean age, 40.4 years, range 27-64) and SARS-CoV-2-negative contacts ( 28 patients, $\mathrm{M} / \mathrm{F} 8 / 20$, mean age, 40.8 years, range $27-68$ ) had comparable demographic characteristics. Severe adult COVID-19 patients (eight patients, M/F 6/2, mean age, 65 years, range 30-90) and mild-symptoms adult COVID-19 patients (eight patients, M/F $5 / 3$, mean age, 55.2 years, range 48-64) were older than asymptomatic patients and controls (Supplementary Table S1). During the study period, disease activity was regularly assessed, and COVID-19 patients continued their therapies according to the standard of care. Four out of eight severe cases were treated with anti-IL-6R monoclonal antibody (tocilizumab). All hospitalized COVID-19 patients were discharged and none died.

\section{Innate Immunity}

The PBMCs of patients with asymptomatic infection, mild and severe disease and their healthy contacts were compared. We correlated the immunological findings with the clinical course and studied the dynamic changes of cells of innate and adaptive immune response in time by analyzing blood samples obtained at weekly intervals beginning on the first or second week after diagnosis.

By flow-cytometry performed on the first sample obtained after diagnosis, we confirmed the increase of MLR in advanced COVID-19 cases, when T cells, normally representing the major lymphocyte population in the peripheral blood, are reduced (32) (Figures 1A, B). Previous studies indicated that neutrophils and macrophages infiltrate the lungs and are expanded in the peripheral blood of Intensive Care Unit (ICU)-admitted patients $(33,34)$. The increase of circulating neutrophils and monocytes, along with lymphopenia, explains why the NLR and MLR are significantly higher in patients with severe COVID-19 disease (10).

$\mathrm{T}$-cell frequencies are preserved in asymptomatic individuals and in patients with mild disease. Thus, in order to investigate whether other lymphocyte populations than $\mathrm{T}$ cells change in asymptomatic and mild disease, we excluded $\mathrm{T}$ cells from the analysis (Figure 1C and Supplementary Figure S1). The CD3 ${ }^{-}$ gate, besides B cells discussed below, includes monocytes that can be distinguished by their larger size measured by the high FCS, and NK cells. NK cells express the markers CD7 (Figure 1C) and CD56 (Supplementary Figure S1).

We found that NK cells were reduced and monocytes increased in patients with severe COVID-19 (Figures 1C, D). Significant reduction of the frequency of NK cells and increase of monocytes were also observed in the group of patients with mild disease (Figures 1C-E). We calculated the Monocyte to NK ratio (MNKR), which was $<1$ in asymptomatic individuals, $>1$ in patients with mild disease and even higher in severe cases (Figure 1E).

These results were confirmed when we analyzed all the samples collected at different time points, as the MNKR remained stable throughout the follow up in asymptomatic and mild disease groups (Figure 2A), because each individual maintained his typical NK and monocyte frequency throughout the time of follow-up (Figure 2B). Thus, the different relative frequencies of monocytes and NK observed in asymptomatic, mild disease and severe cases were not incidental findings observed in a particular moment of the infection, but rather characteristics of the clinical course of the response of the individual immune system to SARS-CoV-2 (Figure 2B). We confirmed the importance of the frequency of NK cells by the analysis of another independent cohort of 77 patients hospitalized because of severe COVID-19. Cases who did not need ICU treatment had a significantly higher number of NK cells $\left(\mathrm{CD}^{+} 6^{+}\right.$cells calculated in $\mathrm{CD}^{-}$lympho-monocyte gate) than ICU patients (Figure 2C). In addition, the percentage of NK cells was low in patients with fatal COVID-19, whereas it increased in those individuals who recovered from severe disease (Figure 2C). These results are corroborated by the observation that ICU patients had lower perforin ${ }^{+} \mathrm{NK}$ cells compared to non-ICU patients (35).

The increase of inflammatory cytokines mostly produced by monocytes plays an important role in determining systemic and local damage in COVID-19. Inflammatory cytokines are produced by intermediate monocytes that expand in the blood of patients with severe infections $(36,37)$. In order to measure the frequency of intermediate monocytes, we used CD16 and CD14 expression to differentiate the three types of $\mathrm{CD}_{14}{ }^{+}$monocytes (Figure 3A) found in the peripheral blood, reflecting sequential stages of maturation and distinct functions $(38,39)$. $\mathrm{CD} 14^{+} \mathrm{CD} 16^{-}$classical monocytes are the precursors of the other types and play an important role in the response to pathogens (40). $\mathrm{CD} 14^{-} \mathrm{CD} 16^{+}$non-classical monocytes contribute to the resolution of inflammation and maintain vascular homeostasis and endothelial integrity (41). Intermediate monocytes express CD14 with variable levels of CD16.

We confirm that, as reported in a recent paper (42), nonclassical monocytes were significantly reduced in patients with severe COVID-19 when compared to SARS-CoV-2 negative contacts, SARS-CoV-2 positive asymptomatic and also mild COVID-19 disease patients (Figure 3B). We also confirm (43) that HLADR expression on CD14+ monocytes was significantly reduced in severe cases (Figure 3B) reflecting the complex immune-dysregulation triggered by the disease (43). Intermediate monocytes tended to increase in the severe cases. As the progression from the classical to intermediate stage is a dynamic step driven by infectious triggers (38), we compared the monocyte phenotype in the same patients at different time points during the course of the disease. Whereas intermediate monocytes were rare in the blood of contacts, asymptomatic and mild disease patients at all time points, transient increases were observed in patients with severe disease (Figure 3C).

In summary, we found that the MNKR reflects the clinical phenotype of the disease. Contact and asymptomatic patients had either higher representation of NK cells or a similar frequency of NK and monocytes (ratio around 1). The ratio was $>1$ in patients with mild disease and reached higher values in 
A
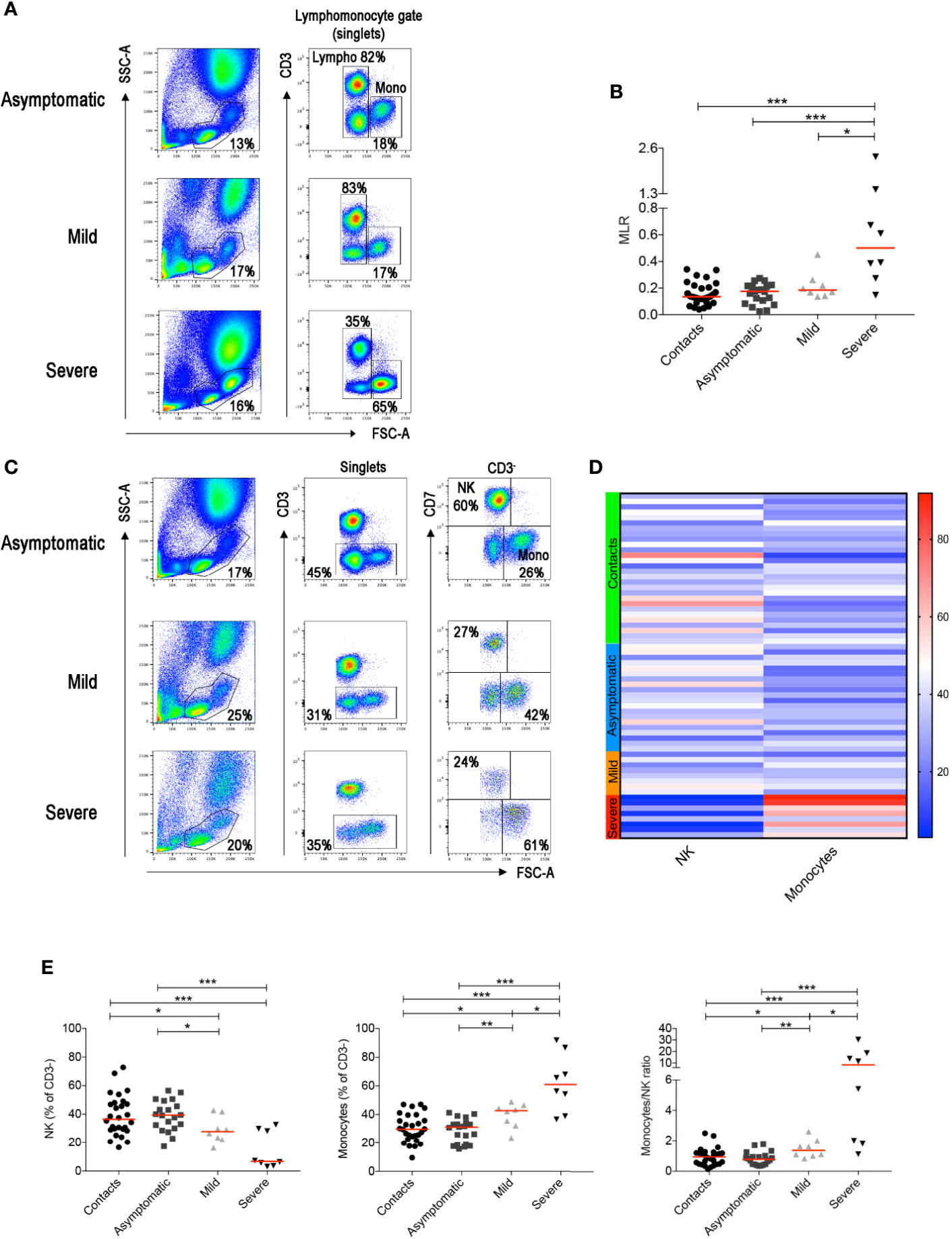

FIGURE 1 | (A) Flow-cytometry analysis of the monocyte to lymphocyte ratio (MLR) in the blood of three representative patients with asymptomatic, mild and severe disease. Total blood (EDTA) was stained with antibodies against CD45, CD3, CD4, CD8, CD7, CD56, CD16. The lympho-monocyte gate was designed based on physical characteristics (FSC-A vs SSC-A). Lymphocytes were gated as FSC-A ${ }^{\text {low }}$ and $\mathrm{CD}^{+}$or $\mathrm{CD}^{-}$and monocytes as CD3 ${ }^{-}$FSC-A ${ }^{\text {high }}$. (B) Scatter plot depicts the MLR in the sixty-four adult patients enrolled in the study (contacts $n=28$; asymptomatic $n=20$; mild $n=8$; severe $n=8$ ). (C) Gating strategy used to identify natural killer (NK) and monocytes inside the $\mathrm{CD}^{-}$cells in three representative patients with asymptomatic, mild and severe disease. NK cells were defined as $\mathrm{CD}^{-} \mathrm{CD} 7^{+} \mathrm{FSC}-\mathrm{A}^{\text {low }}$ and monocytes as $\mathrm{CD}^{-} \mathrm{CD} 7^{-} \mathrm{FSC}-\mathrm{A}^{\text {high }}$. (D) Heatmap shows percentages of NK and monocytes in contacts (indicated by the light green bar), asymptomatic (blue), mild (orange) and severe (red) patients. Percentages are represented by the different expression of red, blue and white as indicated in the color code. (E) Plots indicate the frequency of NK, monocytes and the monocytes/NK ratio (MNKR) in our patients. (B, E) Midlines indicate median. Statistical significances were determined using unpaired, two-tailed Mann-Whitney U-tests. ${ }^{\star} p \leq 0.05,{ }^{\star \star} p<0.01,{ }^{\star \star \star} p<0.001$. 
A

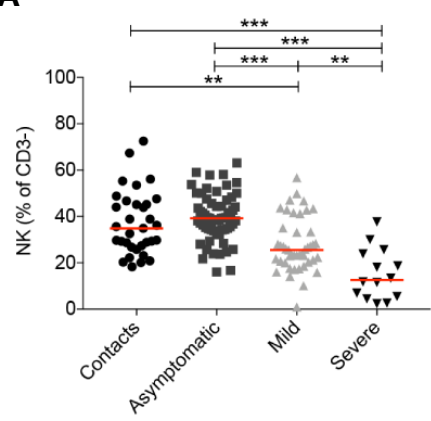

B

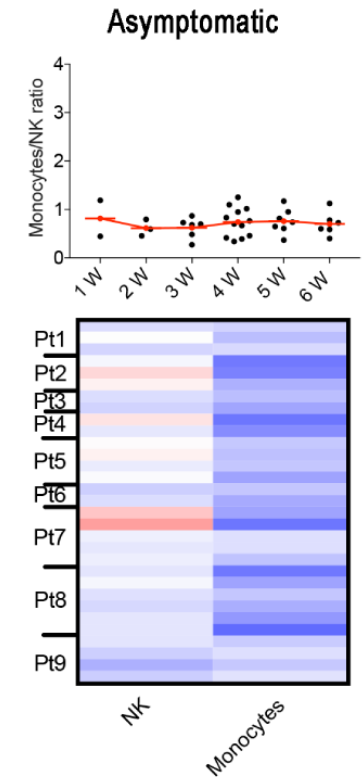

C

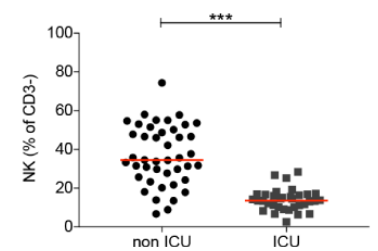

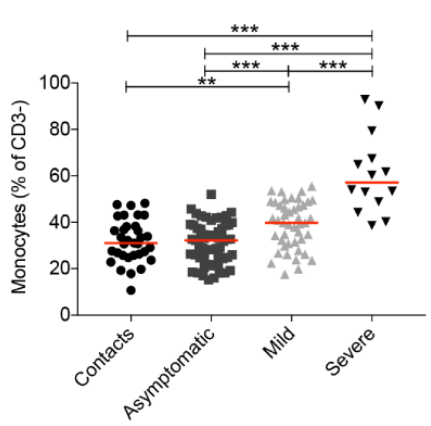

Mild
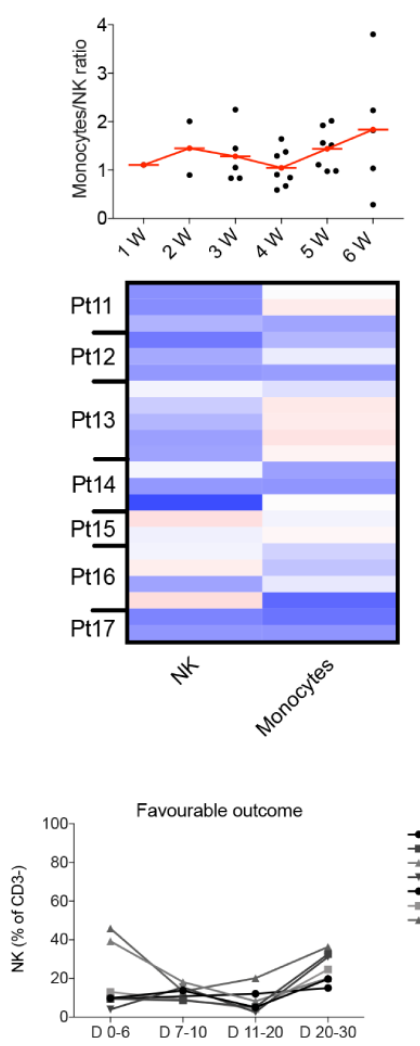
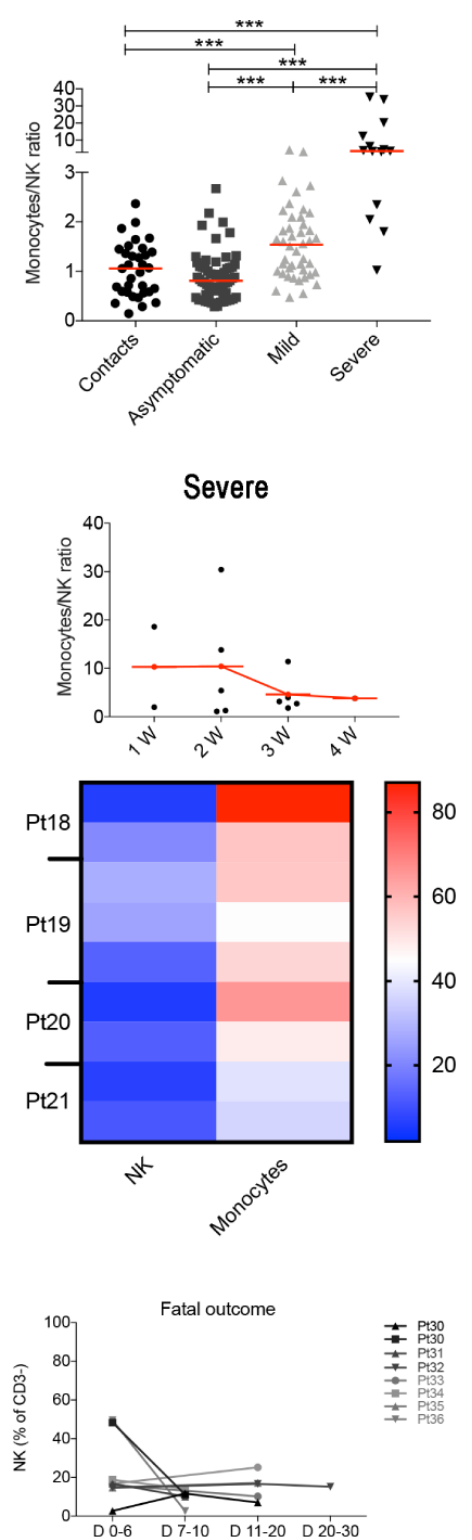

FIGURE 2 | (A) Plots indicate the frequency of NK, monocytes and MNKR ratio in all analyzed samples collected at different time points. (B) Graphs depict the kinetics of the MNKR during the first 6 weeks of disease (midlines indicate mean) in all patients samples. Data referring to severe patients has a different scale due to the high value of MNKR. Heatmaps show the percentage of NK and monocytes in patients who had samples collected at different time points during the first 6 weeks. In the heatmap percentages are represented by the different expression of red, blue and white as indicated in the color code. (C) Scatter plot shows the percentage of NK cells in non-ICU $(n=43)$ and ICU $(n=34)$ patients. Graphs show the kinetics over time of NK cells percentage in patients with favorable and fatal outcome. (A, C) Midlines indicate median. Statistical significances were determined using unpaired, two-tailed Mann-Whitney $U$-tests. ${ }^{* \star} p<0.01,{ }^{\star \star \star} p<0.001$.

the severe cases (Figure 2B). Thus, the equilibrium between two cell types of the innate immune system may play a role in the control of SARS-CoV-2 infection. Prevalence of NK cells is associated to asymptomatic infection, while increased frequency of monocytes to severe disease.

\section{Adaptive Immunity}

$\mathrm{T}$ and $\mathrm{B}$ cells play key roles in response to viral infections. $\mathrm{CD}^{+} \mathrm{T}$ lymphocytes are crucial for the limitation of viral spread through their cytotoxic function. $\mathrm{CD} 4^{+} \mathrm{T}$ cells are indispensable for the expansion of $\mathrm{CD}^{+} \mathrm{T}$ cells (44) and the generation of $\mathrm{CD}^{+}$memory $\mathrm{T}$ cells $(45,46)$. In addition, $\mathrm{CD}^{+} \mathrm{T}$ cells are necessary for the germinal centre (GC) response and the production of memory B cells (MBCs) and plasma cells (4749). As demonstrated before $(35,50)$, we found that $\mathrm{CD}^{+} \mathrm{T}$ cells were reduced only in severe COVID-19 patients (Figure 4A). In this group the frequency of activated $\mathrm{HLADR}^{+} \mathrm{CD}^{+} \mathrm{T}$ cells significantly increased in line with previous observations based 
A

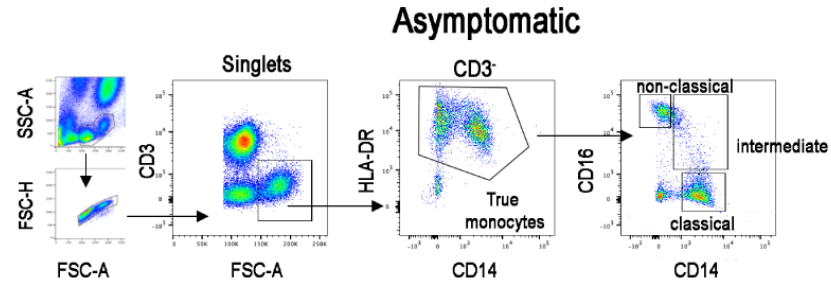

Mild

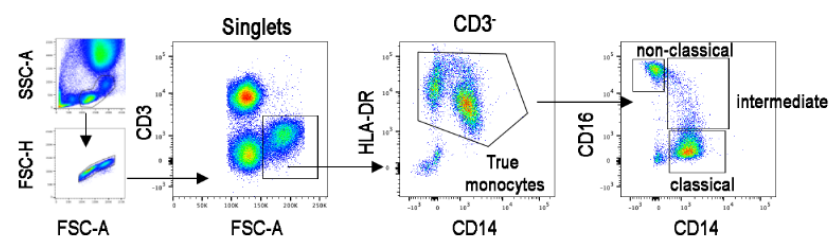

Severe

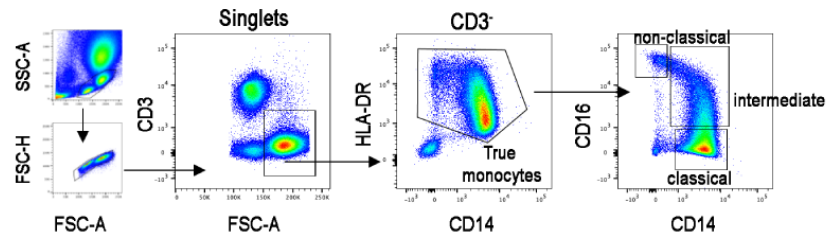

B

Classical

Intermediate

Non classical

HLADR expression

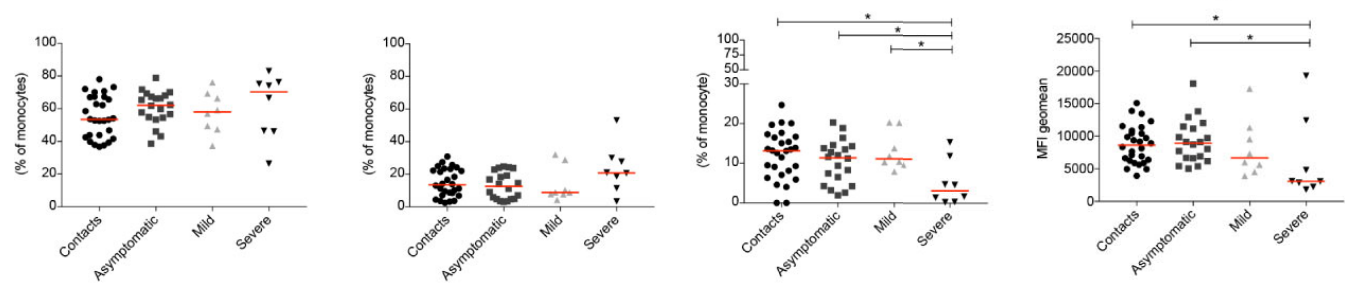

C

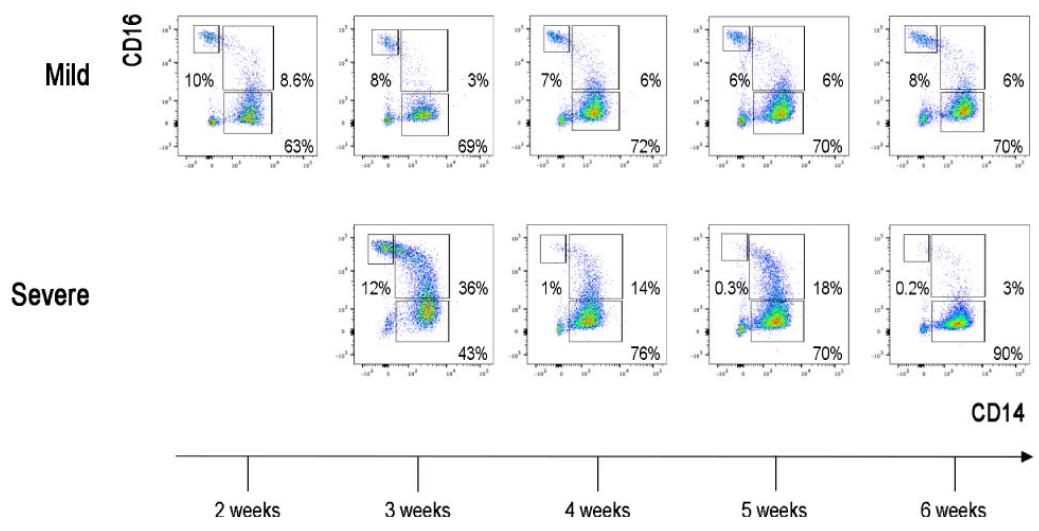

FIGURE 3 | (A) Total blood was stained with antibodies against CD45, CD3, CD4, CD8, CD14, CD16, CD33, CD38 and HLADR. FACS plot show the gating strategy for the identification of monocytes (CD3 ${ }^{-}$FSC- $\left.{ }^{\text {high }}\right)$ in three representative patients with asymptomatic, mild and severe disease. True monocytes are double positive for HLADR and CD14. In the true monocytes gate, we identified the classical $\left(C D 14^{++} C D 16\right)$, intermediate $\left(C D 14^{+} C D 16^{+}\right)$and non-classical $\left(C D 14^{+} C D 16^{++}\right)$ populations. (B) Scatter plots indicate the percentage of classical, intermediate and non-classical monocytes in each group of patients reported as single value. The Mean Fluorescence Intensity (MFI) of HLADR on total monocytes is shown by the last scatter plot. Midlines indicate median. Statistical significances were determined using unpaired, two-tailed Mann-Whitney U-tests. ${ }^{*} p \leq 0.05$. (C) FACS plots show the different distribution of monocytes populations in two representative patients (one mild and one severe) during the course of the disease (2-6 weeks). 
A

B
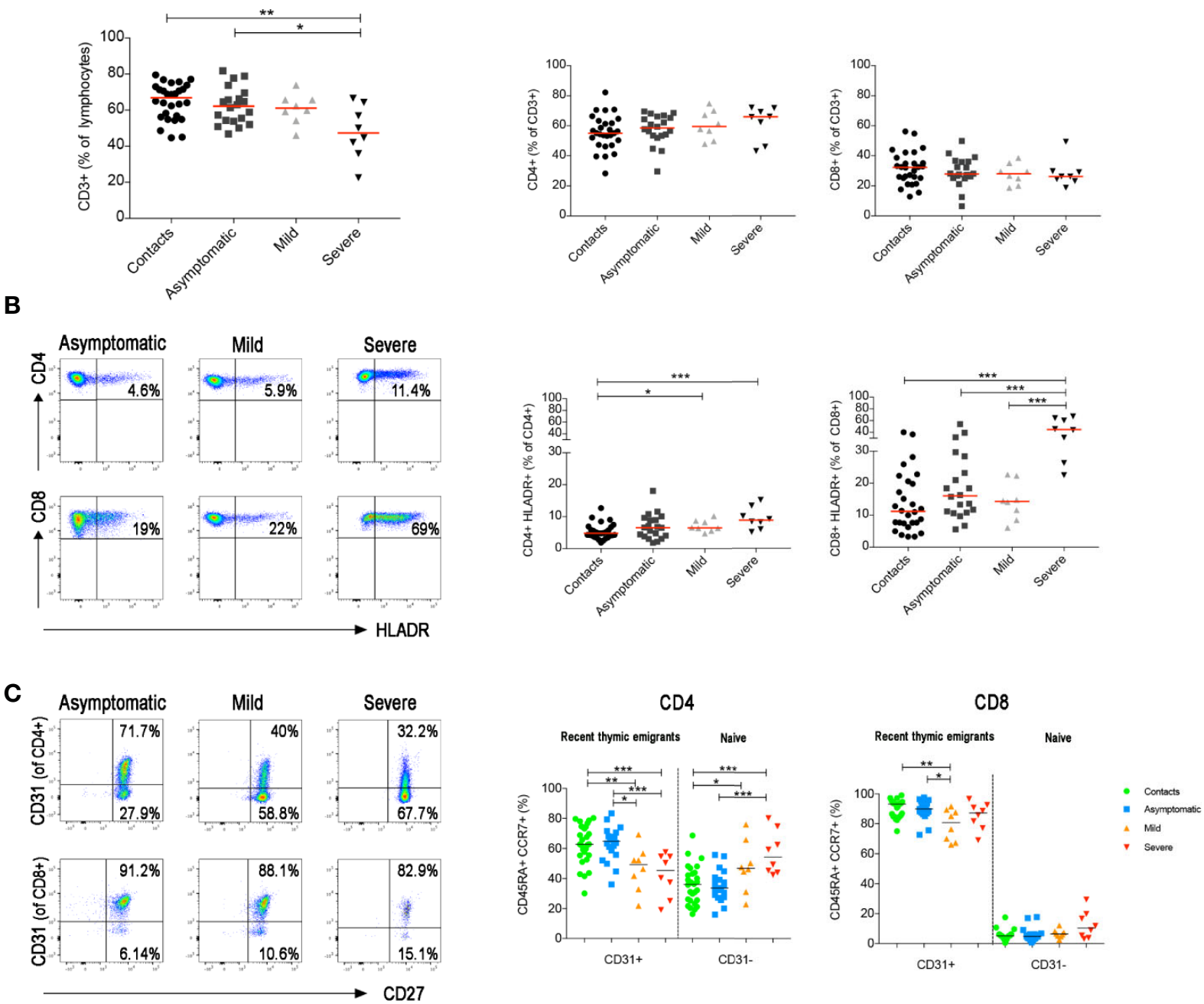

\section{D}

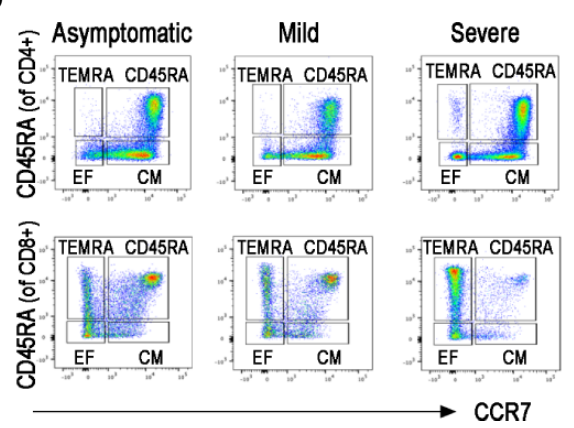

CD4

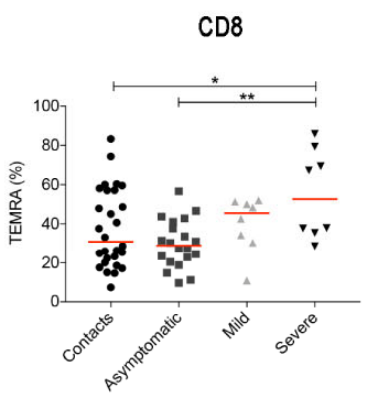

FIGURE 4 | Total blood was stained with antibodies against CD45, CD3, CD4, CD8, CD14, CD16, CD33, CD38 and HLADR and in a second staining antibodies used were anti-CD3, CD4, CD8, CD45RA, CD27, CD28, CD31 and CCR7. (A) Graphs indicate the percentage of total $\mathrm{CD}^{+}, \mathrm{CD}^{+} \mathrm{CD} 4^{+}$and $\mathrm{CD} 3^{+} \mathrm{CD} 8^{+} \mathrm{T}$ cells. (B) FACS plots depict the gating strategy to measure the frequency of $C D 4^{+}$and $C D 8^{+} T$ cells expressing HLADR in three representative patients (asymptomatic, mild and severe). Percentage of $C D 4^{+} H L A D R^{+}$or $C D 8^{+} H L A D R^{+} T$ cells is shown in the relative graphs (at the first sample collected after diagnosis). (C) Pseudocolor plots show $\mathrm{CD} 31$ expression in $\mathrm{CD} 4^{+}$and $\mathrm{CD} 8^{+}$naive $\mathrm{T}$ cells $\left(\mathrm{CD} 3^{+} \mathrm{CCR} 7^{+} \mathrm{CD} 45 \mathrm{RA} \mathrm{A}^{+}\right)$. CD $31^{+}$are recent thymic emigrants and $\mathrm{CD} 31^{-}$are naive $\mathrm{T}$ cells. Graphs show the percentage of $\mathrm{CD} 31^{+}$and $\mathrm{CD} 31^{-} \mathrm{T}$ cells in all patients (at the first sample collected after diagnosis). (D) FACS plots show $\mathrm{CD} 4^{+}$or $\mathrm{CD} 8^{+}$central memory $\left(C D 3^{+} \mathrm{CCR} 7^{+} \mathrm{CD} 45 \mathrm{RA} \mathrm{A}^{-}\right)$, effector memory $\left(\mathrm{CD} 3^{+} \mathrm{CCR} 7^{-} \mathrm{CD} 45 \mathrm{RA}{ }^{-}\right) \mathrm{T}$ cells and TEMRA $\left(\mathrm{CD} 3^{+} \mathrm{CCR} 7^{-} \mathrm{CD} 45 \mathrm{RA} \mathrm{A}^{+}\right) \mathrm{T}$ cells. Scatter plots depict the percentage of $\mathrm{CD} 4^{+}$ and $C D 8^{+}$TEMRA (at the first sample collected after diagnosis). Median is shown as midline. Statistical significances were determined using unpaired, two-tailed Mann-Whitney U-tests. ${ }^{*} p \leq 0.05,{ }^{* \star} p<0.01,{ }^{* * *} p<0.001$. 
on transcriptomic analysis (51), whereas activated $\mathrm{HLADR}^{+}$ CD4 $\mathrm{T}$ cells were measurable in patients with both mild and severe disease (Figure 4B). All these findings were confirmed when we included all serially collected samples in the analysis (Supplementary Figure S2A and B).

In a separate staining, we identified naïve and memory $T$ cells, including central, effector and terminally differentiated (TEMRA) memory $\mathrm{T}$ cells (gating strategy in Supplementary Figure S3). We detected a reduction of recent thymic emigrants $\left(\mathrm{CD} 45 \mathrm{RA}^{+} \mathrm{CCR} 7^{+} \mathrm{CD} 31^{+}\right)$and a relative increase of naïve $\left(\mathrm{CD} 45 \mathrm{RA}^{+} \mathrm{CCR}^{+} \mathrm{CD}^{-} 1^{-}\right) \mathrm{CD}^{+} \mathrm{T}$ cells in both mild and severe disease patients (Figure 4C and Supplementary Figure S2C). $\mathrm{CD}^{+} \mathrm{T}$ cell distribution was only changed in patients with severe disease. CD8 naïve T cells were reduced and, as reported before $(52,53)$ exhausted CD8 ${ }^{+}$TEMRA were significantly increased (Figure 4D and Supplementary Figure S2D).

We identified the different B-cell populations in the peripheral blood by staining with a combination of antibodies able to distinguish transitional, naïve, memory, atypical MBCs and plasmablasts (PBs) (Figure 5A). In the $\mathrm{CD}_{2} 7^{+} \mathrm{MBC}$ population, we separately analyzed $\operatorname{IgM}^{+}$and switched MBCs. The latter include $\mathrm{IgG}^{+}$MBCs and $\mathrm{IgG}^{-}$MBCs. Most of the $\mathrm{IgG}^{-} \mathrm{B}$ cells correspond to IgA-expressing memory $\mathrm{B}$ and in minimal part to MBCs without detectable surface immunoglobulin (Supplementary Figure S4A). The most significant findings were the reduction of total $\mathrm{B}$ cells and the increase of PBs in the severe cases (Figure 5B), as reported in other studies (54-56). Among MBCs, we found an increase of $\operatorname{IgM}^{+}$and a reduction of switched MBCs in asymptomatic and mild cases (Figure 5C). In patients with severe disease, in contrast, we observed an increase of switched MBCs negative for IgG and mostly expressing IgA (Figure 5D). All the findings were confirmed by the cumulative analysis of all samples (Supplementary Figures S4B-D).

$\mathrm{B}$ cells fight viruses by producing antibodies when they differentiate into circulating PBs or tissue-resident plasma cells (57). The final stages of differentiation can be reached by B cells in the GCs, where either naïve or $\operatorname{IgM}^{+} \operatorname{MBCs}(58,59)$ acquire somatic mutations and are selected for their increased affinity to the stimulating antigen (48). T- and GC-independent antibody production is efficiently and rapidly triggered by TLR-mediated stimulation of MBCs $(60,61)$.

IgG and IgA antibodies directed against the $\mathrm{S} 1$ domain of the SARS-CoV-2 Spike protein were measured in the entire study cohort. We also measured the concentrations of IgM specific for the SARS-CoV-2 RBD.

When we analyzed all samples collected throughout the study we observed that both COVID-19 patients and SARS-CoV-2 positive asymptomatic individuals produced specific antibodies, with higher levels of IgG and IgA being detected in the serum of patients with severe disease (Figure 6A) as reported before (18, $26,28,52)$. IgM antibodies were instead equally increased in asymptomatic, mild and severe disease (Figure 6A).

We show in detail the kinetics of the antibody response of asymptomatic and mild disease individuals initiating from the earliest sample obtained after the first positive nasopharyngeal swab (Figures 6B, C).
We found that asymptomatic patients secrete specific IgA and IgM early after diagnosis. As for IgA and IgG there is an established threshold of positivity (dashed line), we could establish that individuals lacking IgG and IgA at week 1, later produced antibodies. Levels of IgA and IgG declined with time as reported by others (62-66). There is no established threshold for anti-RBD IgM, but we found that the median IgM concentration in 54 healthy contacts was $2.1 \mu \mathrm{g} / \mathrm{ml}$ (range $0.3-5.4$ ). We found that IgM levels remained stable over the mean value of contacts in most asymptomatic individuals (Figure 6B).

In Figure 6C we show the antibody response of mild disease patients. In this group values below the threshold were found in two individuals, throughout the course of disease. Pt14, an otherwise healthy 48 year-old HCW, never produced IgG, IgA or IgM (five samples were evaluated). She had neurological symptoms and a positive nasopharyngeal swab PCR for 6 weeks. Pt12 (54-year-old), with respiratory symptoms and a PCR that remained positive for 8 weeks, had very low IgG, IgA and IgM levels fluctuating around the detection threshold. In the rest of the mild disease patients, IgA, IgG, and IgM abs increased later than in asymptomatic individuals but remained over the threshold for 9 weeks.

In summary, we observed that severe patients showed a strong antibody response in line with other observations (18, $26,28,52,67)$. Levels of $\operatorname{IgA}$ and $\operatorname{IgG}$ in asymptomatic individuals returned to levels comparable to those measured in healthy contacts 6-8 weeks from the first positive swab. Antibodies did not decline rapidly in mild disease patients.

\section{DISCUSSION}

The first response to a novel virus is typically characterized by the cooperation between NK cells and natural antibodies, key components of innate immune system (68-72). Since the adaptive response requires time to build up after first encounter with an unknown pathogen, NK cells and natural antibodies contain the infection, whilst adaptive immune responses develop and generate highly-specific memory $\mathrm{T}$ and $B$ cells that will clear the virus and prevent re-infection (22).

We still do not know whether the infection with SARS-CoV-2 triggers this typical response. We do know that individual immune responses play an important role in determining the clinical course of SARS-CoV-2 infection.

In order to understand the basis of the immune response in COVID-19, we performed a global analysis of innate and adaptive immunity in patients selected across the spectrum of disease severity, ranging from SARS-CoV-2 positive asymptomatic individuals to patients with mild and severe COVID-19. We used standard flow-cytometry and serology with the aim of finding an easy-to-use tool for the clinics.

Our data show that the balance between NK cells and monocytes is a sensitive indicator of the individual reaction to the virus and is related to the clinical course of the disease (Figures 1D, E). We calculated the ratio between the frequency of peripheral blood monocyte and NK cells (MNKR) and found 
A
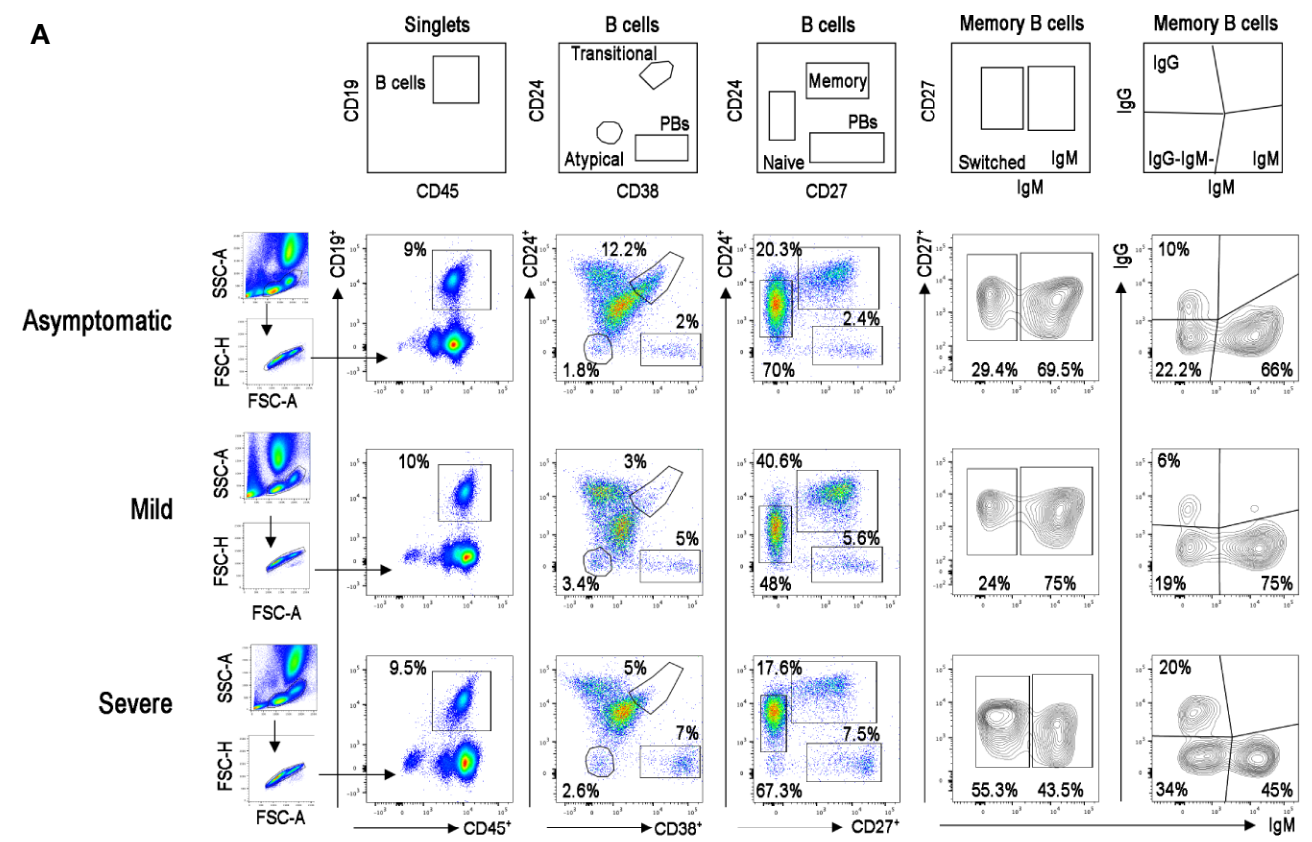

B

C
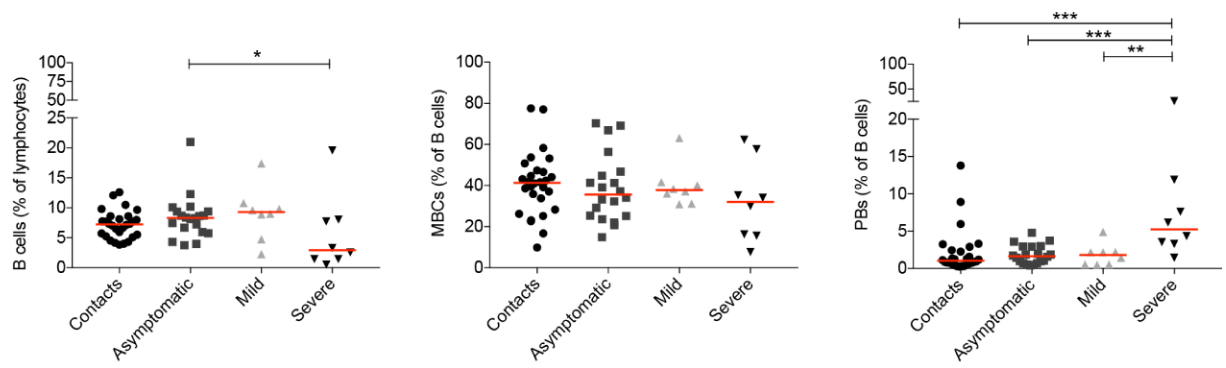

FIGURE 5 | For the staining of the B cells we used the B-cell tube (BD biosciences) that includes: CD19, CD24, CD27, CD38, IgM, IgG, IgD, and CD21. (A) Viable lymphocytes were gated and then selected as $\mathrm{CD} 19^{+} \mathrm{B}$ cells in three representative patients with asymptomatic, mild and severe disease. The identification of the different B-cell populations is shown in the empty plots of the upper line. We identified transitional $\left(\mathrm{CD} 24^{+} \mathrm{CD} 38^{++}\right)$, naive $\left(\mathrm{CD} 24^{+} \mathrm{CD} 27^{-}\right)$, memory $\left(\mathrm{CD} 24^{+} \mathrm{CD} 27^{+}\right)$, atypical MBCs $\left(\mathrm{CD} 24^{-} \mathrm{CD} 38^{-}\right)$and plasmablasts $\left(\mathrm{CD} 24^{-} \mathrm{CD} 27^{++} \mathrm{CD} 38^{++}\right)$. In the $\mathrm{CD} 27^{+}$memory B-cell population based on IgM expression, we show IgM and switched $\left(\mathrm{IgM}^{-}\right)$MBCs. MBCs were also gated as $\operatorname{lgM}^{+}$, $\operatorname{lgG}^{+}$and $\operatorname{lgG}^{-} \operatorname{lgM}{ }^{-}$MBCs. (B) Plots indicate the percentage of $B$ cells, MBCs and plasmablasts. In (C) the frequencies of $\operatorname{lgM}$ and switched MBCs are shown. In panel (D) we show the frequency of $\lg G^{+}$and $\operatorname{lgG}^{-} \operatorname{lgM}^{-}{ }^{-} \mathrm{MBCs}$. Midlines indicate median. Statistical significances were determined using unpaired, two-tailed Mann-Whitney $U$-tests. ${ }^{\star} p \leq 0.05,{ }^{* \star} p<0.01,{ }^{\star \star \star} p<0.001$. 

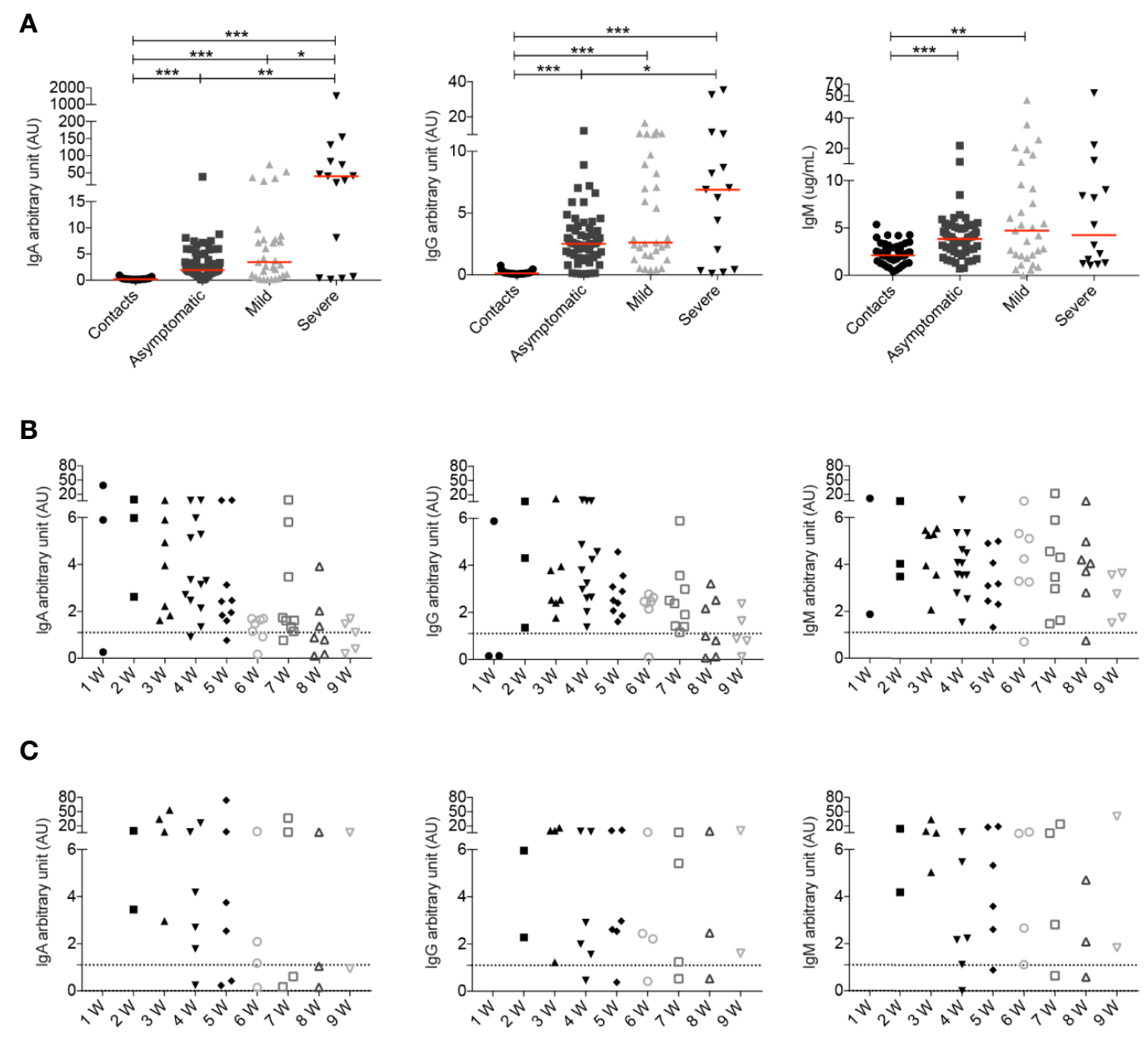

FIGURE 6 | (A) Arbitrary units (AU) of IgG and IgA specific for the S1 domain of the SARS-CoV-2 Spike protein and concentration of RBD specific IgM were detected by ELISA at different time points. For some patients we had the opportunity to have serum samples at different time points of the disease. Data relative to all samples collected are shown (Contacts $n=51$; Asymptomatic $n=63$; Mild $n=31$; Severe $n=15$ ). Midlines indicate median. Statistical significances were determined using unpaired, two-tailed Mann-Whitney $U$-tests. ${ }^{*} \mathrm{p} \leq 0.05,{ }^{* *} \mathrm{p}<0.01,{ }^{\star * *} \mathrm{p}<0.001$. (B, C) Graphs show the levels of IgA, IgG and IgM during the course of the disease in asymptomatic $\mathbf{( B )}$ and mild $\mathbf{( C )}$ patients. Time is indicated in weeks starting from the first positive nasopharyngeal swab. Dashed line indicates detection threshold (1.1).

that each individual included in our study maintained his typical MNKR throughout the time of follow-up (Figure 2B). The MNKR is below 1 in contacts and asymptomatic individuals and increases when monocytes expand, and NK cells are reduced. This phenomenon occurs in mild COVID-19, when the frequency of NK cell slightly declines and that of monocytes increases and is more and is more evident in patients with severe disease, where the loss of NK cells is associated to the expansion of monocytes (Figure 2B). Monocytes secrete inflammatory cytokines causing local and systemic damage (73-75). These alterations are reminiscent of Hemophagocytic Lymphohistiocytosis (HLH), a condition often related to mutations of genes governing the cytotoxic lymphocyte machinery indispensable for the function of NK cells. In HLH, chronic expansion and activation of monocytes cause the life-threatening condition known as cytokine storm (76-79). A similar "storm" is also responsible for the dramatic evolution of severe COVID-19. In these cases, therapeutic strategies aiming at controlling excessive proinflammatory cytokine levels have been successfully used $(80,81)$.

In most viral infection the production of type 1 Interferons (IFN-I) promotes NK cell expansion (82) and has a direct antiviral effects (83). It has been demonstrated that antiviral IFN-I and III are not significantly induced by SARS-CoV-2 infection of respiratory epithelial cells, whereas a chemokines signature is established (84). As a consequence, NK cells survival and function are not supported, but monocytes are attracted to the site of infection. IFN beta-1 was administered as early treatment together with a triple combination of anti-viral drugs in a recently published multicenter, open randomized trial. The therapy was effective in suppressing the shedding of SARS-CoV-2 by acting on virus replication and innate immunity (85). In agreement with our hypothesis it has been demonstrated 
that inborn error of type I IFN immunity and neutralization of type I IFN function by autoantibodies are associated to the most severe forms of COVID-19 $(86,87)$.

It has been reported that antibodies are produced late in hospitalized patients with COVID-19: IgG increased after three weeks and IgM antibodies were transiently detected often later than $\operatorname{IgG}(16,24)$. Earlier antibody production has been shown more recently $(88,89)$.

We measured the specific response to the S1 domain of the SARS-CoV-2 spike protein (IgG and IgA) and to the RBD (IgM) in the serum of all patients and controls in our study at different time points (Figure 6). We confirm that the highest levels of IgG and also IgA are produced by patients with severe disease. Our most interesting observation is the different kinetics of response in asymptomatic and mild disease forms of infection. The early and transient IgM, IgA, and IgG responses distinguish asymptomatic individuals from mild-disease patients, who have a slower, but more persistent antibody production (Figure 6).

In asymptomatic individuals, the early burst of IgA may rapidly and effectively eliminate the virus in the respiratory mucosa and prevent the development of a full adaptive immune reaction. The slightly slower IgG and IgA production that persist in time suggests that the adaptive immune response is triggered in mild disease and may be able to generate immunological memory. A long and severe disease fully activates the adaptive immune response and is associated with the production of anti-SARS-CoV-2 antibodies, PBs and memory B cells (90). Further studies are necessary to establish whether specific memory persist and for how long after asymptomatic and mild disease.

The particular antigen-specific IgA/IgG profile associated with clinical outcome may reflect TGFbeta production induced by coronavirus-species $(91,92)$. Augmented viral load may increase TGFbeta production, that, if locally secreted in the lung, facilitates neutrophil attraction and specifically induces the isotype switch to IgA (93), a situation that prompted the suggestion of anti-TGFbeta directed immunotherapies $(94,95)$.

Innate MBCs are increased in asymptomatic and mild disease. Innate MBCs produce natural antibodies in response to TLR stimulation $(60,96)$ but are also able to enter the GC where they remodel their antibodies to increase their affinity $(58,97) . \operatorname{IgM}^{+}$ MBCs are the precursors of most $\mathrm{IgA}^{+}$and $\mathrm{IgG}^{+}$switched MBCs (97) and give rise to $\operatorname{IgA}^{+}$plasma cells at mucosal site (98). 'Natural antibodies', produced by innate MBCs, are antibodies that have a protective role in the early phases of the response independently of any previous encounter with antigen (96, 99, 100). These antibodies, have not yet been shaped by antigenic selection, carry few somatic mutations (58) and have broad reactivity (101). We recently suggested that natural antibodies might explain why most pediatric cases with laboratoryconfirmed SARS-CoV-2 infection have either no or mild symptoms and recover within 1-2 weeks (102). Cross-reactive antibodies found in children and adult never exposed to SARSCoV-2 (103) may correspond to natural antibodies. We speculate that the early IgA burst of asymptomatic individuals may derive from the rapid activation of pre-existing innate or cross-reactive $\operatorname{IgM}^{+} \mathrm{MBC}$ that switched to IgA in the respiratory mucosa (25), as suggested also by the demonstration that moderate levels of IgM and IgA cross-reactive to SARS-CoV-2 are present in the blood of healthy individuals never exposed to the infection (103). In addition, neutralizing IgG MBCs isolated from COVID-19 patients may have none or very few somatic mutations (104) thus suggesting that the pre-immune or innate $\mathrm{MBC}$ repertoire may contain SARS-CoV-2 specificities (89). In patients with severe COVID-19, $\operatorname{IgM}^{+}$MBCs are reduced and switched MBCs are increased (Figure 5C). The increase of switched MBCs may reflect the immune reaction in the lymphoid tissue associated to the respiratory tree for local protection. Circulating PBs are also increased only in the severe cases in correlation with their higher antibody levels.

Our analysis of circulating $\mathrm{T}$ cells shows that SARS-COV-2 infection does not alter the $\mathrm{T}$ cell pool in asymptomatic individuals (Figure 4). In mild and severe COVID-19, instead, the increase of activated $\mathrm{CD}^{+} \mathrm{T}$ cells reflects the ongoing immune activation (Figure 4B). Activated $\mathrm{CD}^{+} \mathrm{T}$ cells are indispensable for the effector function during acute viral infections and for the expansion of $\mathrm{CD}^{+} \mathrm{T}$ cells (105). In severe cases, also $\mathrm{CD}^{+} \mathrm{T}$ cell are activated (Figure 4B), as also reported in a recent study analyzing the immune response in 76 COVID-19 patients from two independent cohorts (54), and TEMRA accumulate in the blood (Figure 4D). A persistent viral antigen stimulation and immune dysregulation may lead to Tcell exhaustion, a state of T-cell dysfunction demonstrated to occur during many chronic infections and cancer (106).

SARS-CoV-2 has evolved in bats, which control the infection through their innate immune system, enriched for NK receptors and different types of INF type I genes (107). Bats also produce antibodies that are highly diverse thanks to a repertoire of $\mathrm{VH}$, $\mathrm{DH}$ and $\mathrm{JH}$ fragments that is much larger than that found in humans $(108,109)$. Antibodies do not undergo further improvement by introduction of somatic mutation. Thus, constitutive IFN type I secretion and ready-to-use antibodies may control viral infection in bats without the need of adaptive immune responses. For this reason, coronaviruses and other viruses remain endemic in bats, without damaging the host (107). Asymptomatic humans may behave like bats, controlling the infection thanks to NK cells and antibodies. The adaptive immune response is strongest in patients with severe disease, following the extensive tissue damage caused by the uncontrolled inflammatory reaction.

Our data may contribute to monitor the clinical disease. Although many large studies have described the inflammatory reaction in severe disease $(76,110)$, clinically it is indispensable to have prognostic markers early in the course of disease in order to promptly choose appropriate treatments (111). The increase of the ratio between Neutrophils (NLR) or Monocytes and lymphocytes (MLR), mainly caused by the loss of lymphocytes, is an indicator of severe disease (3), but does not change in less severe forms when lymphocytes numbers are still maintained (Figure 1B). We propose that the monocyte to NK ratio (MNKR) and the levels of specific $\operatorname{IgG}, \operatorname{IgA}$ and $\operatorname{IgM}$ 
antibodies in the serum may be more sensible early markers of disease evolution. In particular, low level of antibodies in the first two weeks after diagnosis and increase of the MNKR may indicate patients at risk for increased severity of disease.

Our study has some limitations: 1) Patients with mild as well as severe disease were significantly older than the asymptomatic cases and contacts. The age range, however, reflects the epidemiology to COVID-19 at the study time. 2) All data on the kinetics of the COVID-19 are generated from the first blood sample collected at the time of the first positive PCR and not from to the date of first COVID-19 symptom. Due to variety of symptoms presentation and the inclusion of asymptomatic individuals, we preferred to use a uniform starting point for all subjects included in the study.

\section{DATA AVAILABILITY STATEMENT}

The original contributions presented in the study are included in the article/Supplementary Material. Further inquiries can be directed to the corresponding author.

\section{ETHICS STATEMENT}

The studies involving human participants were reviewed and approved by Bambino Gesù Children Hospital. The patients/ participants provided their written informed consent to participate in this study.

\section{AUTHOR CONTRIBUTIONS}

RC, SZ, IQ, and FL designed the study and performed data analysis and manuscript preparation. EM and ST performed data experiments and data analysis and helped with manuscript preparation. FC, CCa, PatP, MMi, SC, EC, LM, EN, and FP performed data experiments. PaoP, IC, CM, VC, MV, AS, OP, CCo, AM, and MR helped with collection of study samples and clinical information. CA, GI, CQ, AZ, and MMa helped with manuscript preparation. All authors contributed to the article and approved the submitted version.

\section{REFERENCES}

1. Zhou F, Yu T, Du R, Fan G, Liu Y, Liu Z, et al. Clinical course and risk factors for mortality of adult inpatients with COVID-19 in Wuhan, China: a retrospective cohort study. Lancet (2020) 395(10229):1054-62. doi: 10.1016/S0140-6736(20) 30566-3

2. Maggi E, Canonica GW, Moretta L. COVID-19: unanswered questions on immune response and pathogenesis. J Allergy Clin Immunol (2020) 146 (1):18-22. doi: 10.1016/j.jaci.2020.05.001

3. Qin C, Zhou L, Hu Z, Zhang S, Yang S, Tao Y, et al. Dysregulation of immune response in patients with COVID-19 in Wuhan, China. Clin Infect Dis (2020) 71(15):762-8. doi: 10.1093/cid/ciaa248

4. Mehta P, McAuley DF, Brown M, Sanchez E, Tattersall RS, Manson JJ. COVID-19: consider cytokine storm syndromes and

\section{FUNDING}

This work was funded by the RF2013-02358960 and COVID2020-12371817 grants from the Italian Ministry of Health.

\section{ACKNOWLEDGMENT}

This manuscript has been released as a pre-print at Medrxiv, doi:10.1101/2020.06.22.20137141.

\section{SUPPLEMENTARY MATERIAL}

The Supplementary Material for this article can be found online at: https://www.frontiersin.org/articles/10.3389/fimmu.2020. 610300/full\#supplementary-material

SUPPLEMENTARY FIGURE 1 | The lympho-monocyte gate was designed based on physical characteristics (FSC-A vs SSC-A). Singlets are identified by FSC-H vs FSC-A parameters. NK were identified as $C D 3^{-} C D 7^{+} F S C-A^{\text {low }}$ and monocytes as $\mathrm{CD}^{-} \mathrm{CD} 7^{-} \mathrm{FSC}-\mathrm{A}^{\text {high }}$. NK cells identified as $\mathrm{CD}^{+}$in the $\mathrm{CD}^{-}$gate also express CD56.

SUPPLEMENTARY FIGURE 2 | (A) Scatter plots show percentage of T cells $\left(C D 3^{+}\right), \mathrm{CD}^{+}$and $\mathrm{CD} 8^{+}$. (B) Plots show the percentage of $\mathrm{CD} 4^{+} \mathrm{HLADR}^{+}$and $\mathrm{CD}^{+} \mathrm{HLADR}^{+} \mathrm{T}$ cells in all sample serially collected and analyzed in the study. (C) Nairve $T$ cells were divided based on CD31 expression (CD31 ${ }^{+}$and CD31'). (D) Plots show the percentage of TEMRA in CD4 ${ }^{+}$and $C D 8^{+} \mathrm{T}$ cells in all sample serially collected and analyzed in the study. Midlines indicate median. Statistical significances were determined using unpaired, two-tailed Mann-Whitney U-tests. ${ }^{\star} \mathrm{p} \leq 0.05,{ }^{* *} \mathrm{p}<0.01,{ }^{* \star *} \mathrm{p}<0.001$.

SUPPLEMENTARY FIGURE 3 | Gating strategy to analyze T cells subset. The $\mathrm{CD}^{+}$and $\mathrm{CD}^{+} \mathrm{T}$ cells were subdivided into the main $\mathrm{T}$ cell subsets. HLADR was used to identify activated $\mathrm{CD} 4^{+}$and $\mathrm{CD} 8^{+} \mathrm{T}$ cells. Using CD45RA and CCR7: naïve $\left(\mathrm{CD} 45 \mathrm{RA}^{+} \mathrm{CCR} 7^{+}\right)$, central memory $\left(\mathrm{CM} \mathrm{CD} 45 \mathrm{RA} \mathrm{A}^{-} \mathrm{CCR} 7^{+}\right)$, effector memory (EM $\mathrm{CD}^{2} 5 \mathrm{RA}^{-} \mathrm{CCR}^{-}$) and TEMRA (CD45RA $\left.{ }^{+} \mathrm{CCR} 7^{-}\right) \mathrm{T}$ cells were identified. Naïve $\mathrm{T}$ cells were further divided based on CD31 expression $\left(\mathrm{CD} 31^{+}\right.$and $\left.\mathrm{CD} 31^{-}\right) . \mathrm{CM}$ and EM were separated based on the expression of CD27 and CD28.

SUPPLEMENTARY FIGURE 4 | (A) FACS plots in three healthy donors indicates that most of $\operatorname{lgG}^{-} \lg M^{-} \mathrm{MBCs}^{-}$correspond to $\lg \mathrm{A}$ expressing MBCs and minimal part of these cells are $\operatorname{lgA}^{-} \operatorname{lgG}^{-} \operatorname{lgM}^{-}$MBCs. (B) Plots indicate the percentage of B cells, MBCs and plasmablasts. In (C) we show the frequencies of IgM and switched MBCs. In (D) we show the frequency of $\operatorname{lgG}^{+}, \operatorname{lgG}^{-} \operatorname{lgM}{ }^{-} \mathrm{MBCs}$. (B-D) Graphs refer to all samples analyzed in the study. Midlines indicate median. Statistical significances were determined using unpaired, two-tailed Mann-Whitney $U$-tests. ${ }^{*} p \leq 0.05,{ }^{\star \star} p<0.01,{ }^{\star \star *} p<0.001$.

immunosuppression. Lancet (2020) 395(10229):1033-4. doi: 10.1016/ S0140-6736(20)30628-0

5. Perlman S, Netland J. Coronaviruses post-SARS: Update on replication and pathogenesis. Nat Rev Microbiol (2009) 7(6):439-50. doi: 10.1038/nrmicro2147

6. Wong CK, Lam CWK, Wu AKL, Ip WK, Lee NLS, Chan IHS, et al. Plasma inflammatory cytokines and chemokines in severe acute respiratory syndrome. Clin Exp Immunol (2004) 136(1):95-103. doi: 10.1111/j.13652249.2004.02415.x

7. Tan L, Wang Q, Zhang D, Ding J, Huang Q, Tang YQ, et al. Lymphopenia predicts disease severity of COVID-19: a descriptive and predictive study. Signal Transduct Target Ther (2020) 5(1):33. doi: 10.1038/s41392-0200148-4

8. Zhao Q, Meng M, Kumar R, Wu Y, Huang J, Deng Y, et al. Lymphopenia is associated with severe coronavirus disease 2019 (COVID-19) infections: A 
systemic review and meta-analysis. Int J Infect Dis (2020) 96:131-5. doi: $10.1016 /$ j.ijid.2020.04.086

9. Perlman S, Dandekar AA. Immunopathogenesis of coronavirus infections: Implications for SARS. Nat Rev Immunol (2005) 5(12):917-27. doi: 10.1038/ nri1732

10. Sun S, Cai X, Wang H, He G, Lin Y, Lu B, et al. Abnormalities of peripheral blood system in patients with COVID-19 in Wenzhou, China. Clin Chim Acta (2020) 507(8):174-80. doi: 10.1016/j.cca.2020.04.024

11. Peng J, Qi D, Yuan G, Deng X, Mei Y, Feng L, et al. Diagnostic value of peripheral hematologic markers for coronavirus disease 2019 (COVID-19): A multicenter, cross-sectional study. J Clin Lab Anal (2020) 34:e23475. doi: $10.1002 /$ jcla.23475

12. Diao B, Wang C, Tan Y, Chen X, Liu Y, Ning L, et al. Reduction and Functional Exhaustion of T Cells in Patients With Coronavirus Disease 2019 (COVID-19). Front Immunol (2020) 11:827. doi: 10.3389/fimmu. 2020.00827

13. Zheng M, Gao Y, Wang G, Song G, Liu S, Sun D, et al. Functional exhaustion of antiviral lymphocytes in COVID-19 patients. Cell Mol Immunol (2020) 17 (5):533-5. doi: 10.1038/s41423-020-0402-2

14. Mateus J, Grifoni A, Tarke A, Sidney J, Ramirez SI, Dan JM, et al. Selective and cross-reactive SARS-CoV-2 T cell epitopes in unexposed humans. Sci (80- ) (2020) 370(6512):89-94. doi: 10.1126/science.abd3871

15. Weiskopf D, Schmitz KS, Raadsen MP, Grifoni A, Okba NMA, Endeman H, et al. Phenotype and kinetics of SARS-CoV-2-specific T cells in COVID-19 patients with acute respiratory distress syndrome. Sci Immunol (2020) 5(48): eabd2071. doi: 10.1126/sciimmunol.abd2071

16. Long QX, Liu BZ, Deng HJ, Wu GC, Deng K, Chen YK, et al. Antibody responses to SARS-CoV-2 in patients with COVID-19. Nat Med (2020) 71 (16):2027-34. doi: 10.1038/s41591-020-0897-1

17. Duan K, Liu B, Li C, Zhang H, Yu T, Qu J, et al. Effectiveness of convalescent plasma therapy in severe COVID-19 patients. Proc Natl Acad Sci (2020) 117 (17):9490-6. doi: 10.1073/pnas.2004168117

18. Okba N, Muller M, Li W, Wang C, GeurtsvanKessel C, Corman V, et al. SARS-CoV-2 specific antibody responses in COVID-19 patients. Emerg Infect Dis (2020) 26(7):1478-88. doi: 10.1101/2020.03.18.20038059

19. Liu L, Wang P, Nair MS, Yu J, Rapp M, Wang Q, et al. Potent neutralizing antibodies directed to multiple epitopes on SARS-CoV-2 spike. Nature (2020) 584:450-6. doi: 10.1038/s41586-020-2571-7

20. Wu F, Wang A, Liu M, Wang Q, Chen J, Xia S, et al. Neutralizing Antibody Responses to SARS-CoV-2 in a COVID-19 Recovered Patient Cohort and Their Implications. SSRN Electron J (2020) 2020.03.30.20047365. doi: $10.2139 /$ ssrn. 3566211

21. Phan TG, Tangye SG. Memory B cells: total recall. Curr Opin Immunol (2017) 45:132-40. doi: 10.1016/j.coi.2017.03.005

22. Kurosaki T, Kometani K, Ise W. Memory B cells. Nat Rev Immunol (2015) 15:149-59. doi: 10.1038/nri3802

23. Lee YL, Liao CH, Liu PY, Cheng CY, Chung MY, Liu CE, et al. Dynamics of anti-SARS-Cov-2 IgM and IgG antibodies among COVID-19 patients. J Infect (2020) 81(2):e55-e8. doi: 10.1016/j.jinf.2020.04.019

24. To KK-W, Tsang OT-Y, Leung W-S, Tam AR, Wu T-C, Lung DC, et al. Temporal profiles of viral load in posterior oropharyngeal saliva samples and serum antibody responses during infection by SARS-CoV-2: an observational cohort study. Lancet Infect Dis (2020) 20(5):565-74. doi: 10.1016/s1473-3099(20)30196-1

25. Padoan A, Sciacovelli L, Basso D, Negrini D, Zuin S, Cosma C, et al. IgA-Ab response to spike glycoprotein of SARS-CoV-2 in patients with COVID-19: A longitudinal study. Clin Chim Acta (2020) 507:164-7. doi: 10.1016/ j.cca.2020.04.026

26. Yu H, Sun B, Fang Z, Zhao J, Liu X, Li Y, et al. Distinct features of SARSCoV-2-specific IgA response in COVID-19 patients. Eur Respir J (2020) 56 (2):2001526. doi: 10.1183/13993003.01526-2020

27. Cao X. COVID-19: immunopathology and its implications for therapy. Nat Rev Immunol (2020) 20:269-70. doi: 10.1038/s41577-020-0308-3

28. Zhao J, Yuan Q, Wang H, Liu W, Liao X, Su Y, et al. Antibody responses to SARS-CoV-2 in patients of novel coronavirus disease 2019. Clin Infect Dis (2020) 71(16):2027-34. doi: 10.1093/cid/ciaa344

29. Zhang B, Zhou X, Zhu C, Song Y, Feng F, Qiu Y, et al. Immune Phenotyping Based on the Neutrophil-to-Lymphocyte Ratio and IgG Level Predicts
Disease Severity and Outcome for Patients With COVID-19. Front Mol Biosci (2020) 7:157. doi: 10.3389/fmolb.2020.00157

30. Wan Y, Shang J, Sun S, Tai W, Chen J, Geng Q, et al. Molecular Mechanism for Antibody-Dependent Enhancement of Coronavirus Entry. J Virol (2019) 94(5):e02015-19. doi: 10.1128/jvi.02015-19

31. WHO Headquarters (HQ). Country \& Technical Guidance - Coronavirus disease (COVID-19) (2020). Available at: https://www.who.int/publications/ $\mathrm{i} /$ item/clinical-management-of-covid-19.

32. He R, Lu Z, Zhang L, Fan T, Xiong R, Shen X, et al. The clinical course and its correlated immune status in COVID-19 pneumonia. J Clin Virol (2020) 127:104361. doi: 10.1016/j.jcv.2020.104361

33. Arabi YM, Balkhy HH, Hayden FG, Bouchama A, Luke T, Baillie JK, et al. Middle east respiratory syndrome. N Engl J Med (2017) 376:584-94. doi: 10.1056/NEJMsr1408795

34. Choi KW, Chau TN, Tsang O, Tso E, Chiu MC, Tong WL, et al. Outcomes and Prognostic Factors in 267 Patients with Severe Acute Respiratory Syndrome in Hong Kong. Ann Intern Med (2003) 139:715-23. doi: 10.7326/0003-4819-139-9-200311040-00005

35. Bordoni V, Sacchi A, Cimini E, Notari S, Grassi G, Tartaglia E, et al. An inflammatory profile correlates with decreased frequency of cytotoxic cells in COVID-19. Clin Infect Dis (2020) 71(16):2272-5. doi: 10.1093/cid/ciaa577

36. Fingerle G, Pforte A, Passlick B, Blumenstein M, Ströbel M, ZieglerHeitbrock HW. The novel subset of CD14+/CD16+ blood monocytes is expanded in sepsis patients. Blood (1993) 82:3170-6. doi: 10.1182/ blood.V82.10.3170.bloodjournal82103170

37. Nockher WA, Scherberich JE. Expanded CD14+ CD16+ Monocyte subpopulation in patients with acute and chronic infections undergoing hemodialysis. Infect Immun (1998) 66(6):2782-90. doi: 10.1128/ iai.66.6.2782-2790.1998

38. Patel AA, Zhang Y, Fullerton JN, Boelen L, Rongvaux A, Maini AA, et al. The fate and lifespan of human monocyte subsets in steady state and systemic inflammation. J Exp Med (2017) 214(7):1913-23. doi: 10.1084/ jem.20170355

39. Wildgruber M, Aschenbrenner T, Wendorff H, Czubba M, Glinzer A, Haller B, et al. The "intermediate" CD14++ CD16+ monocyte subset increases in severe peripheral artery disease in humans. Sci Rep (2016) 6:39483. doi: 10.1038/ srep39483

40. Kapellos TS, Bonaguro L, Gemünd I, Reusch N, Saglam A, Hinkley ER, et al. Human monocyte subsets and phenotypes in major chronic inflammatory diseases. Front Immunol (2019) 10:2035. doi: 10.3389/fimmu.2019.02035

41. Narasimhan PB, Marcovecchio P, Hamers AAJ, Hedrick CC. Nonclassical Monocytes in Health and Disease. Annu Rev Immunol (2019) 37:439-56. doi: 10.1146/annurev-immunol-042617-053119

42. Schulte-Schrepping J, Reusch N, Paclik D, Baßler K, Schlickeiser S, Zhang B, et al. Severe COVID-19 Is Marked by a Dysregulated Myeloid Cell Compartment. Cell (2020) 182:1419-40. doi: 10.1016/j.cell.2020.08.001

43. Giamarellos-Bourboulis EJ, Netea MG, Rovina N, Akinosoglou K, Antoniadou A, Antonakos N, et al. Complex Immune Dysregulation in COVID-19 Patients with Severe Respiratory Failure. Cell Host Microbe (2020) 27(6):992-1000. doi: 10.1016/j.chom.2020.04.009

44. Shedlock DJ, Shen H. Requirement for CD4 T cell help in generating functional CD8 T cell memory. Sci (80- ) (2003) 300(5617):337-9. doi: 10.1126/science. 1082305

45. Laidlaw BJ, Craft JE, Kaech SM. The multifaceted role of CD4+ T cells in CD8+ T cell memory. Nat Rev Immunol (2016) 16(2):102-11. doi: 10.1038/ nri.2015.10

46. Janssen EM, Lemmens EE, Wolfe T, Christen U, Von Herrath MG, Schoenberger SP. CD4+ T cells are required for secondary expansion and memory in CD8+ T lymphocytes. Nature (2003) 421(6925):852-6. doi: 10.1038/nature01441

47. Ramiscal RR, Vinuesa CG. T-cell subsets in the germinal center. Immunol Rev (2013) 252(1):146-55. doi: 10.1111/imr.12031

48. Victora GD, Schwickert TA, Fooksman DR, Kamphorst AO, MeyerHermann M, Dustin ML, et al. Germinal center dynamics revealed by multiphoton microscopy with a photoactivatable fluorescent reporter. Cell (2010) 143:592-605. doi: 10.1016/j.cell.2010.10.032

49. Crotty S. Follicular helper CD4 T cells (TFH). Annu Rev Immunol (2011) 29:621-63. doi: 10.1146/annurev-immunol-031210-101400 
50. Chen N, Zhou M, Dong X, Qu J, Gong F, Han Y, et al. Epidemiological and clinical characteristics of 99 cases of 2019 novel coronavirus pneumonia in Wuhan, China: a descriptive study. Lancet (2020) 395(10223):507-13. doi: 10.1016/S0140-6736(20)30211-7

51. Zhang JY, Wang XM, Xing X, Xu Z, Zhang C, Song JW, et al. Single-cell landscape of immunological responses in patients with COVID-19. Nat Immunol (2020) 21:1107-18. doi: 10.1038/s41590-020-0762-x

52. Wen W, Su W, Tang H, Le W, Zhang X, Zheng Y, et al. Immune cell profiling of COVID-19 patients in the recovery stage by single-cell sequencing. Cell Discovery (2020) 6:31. doi: 10.1038/s41421-020-0168-9

53. Weiskopf D, Schmitz KS, Raadsen MP, Grifoni A, Okba NMA, Endeman $\mathrm{H}$, et al. Phenotype and kinetics of SARS-CoV-2 \{ltextendash $\}$ specific $T$ cells in COVID-19 patients with acute respiratory distress syndrome. Sci Immunol (2020) 5(48):eabd2071. doi: 10.1126/sciimmunol.abd2071

54. Arunachalam PS, Wimmers F, Mok CKP, Perera RAPM, Scott M, Hagan T, et al. Systems biological assessment of immunity to mild versus severe COVID-19 infection in humans. Sci (80- ) (2020) 369:1210-20. doi: 10.1126/ science.abc6261

55. Zhu L, Yang P, Zhao Y, Zhuang Z, Wang Z, Song R, et al. Single-Cell Sequencing of Peripheral Mononuclear Cells Reveals Distinct Immune Response Landscapes of COVID-19 and Influenza Patients. Immunity (2020) 53(3):685-96. doi: 10.1016/j.immuni.2020.07.009

56. Wilk AJ, Rustagi A, Zhao NQ, Roque J, Martínez-Colón GJ, McKechnie JL, et al. A single-cell atlas of the peripheral immune response in patients with severe COVID-19. Nat Med (2020) 26:1070-6. doi: 10.1038/s41591-020-0944-y

57. Dörner T, Radbruch A. Antibodies and B Cell Memory in Viral Immunity. Immunity (2007) 27(3):384-92. doi: 10.1016/j.immuni.2007.09.002

58. Aranburu A, Piano Mortari E, Baban A, Giorda E, Cascioli S, Marcellini V, et al. Human B-cell memory is shaped by age- and tissue-specific Tindependent and GC-dependent events. Eur J Immunol (2017) 47(2):32744. doi: 10.1002/eji.201646642

59. Victora GD, Nussenzweig MC. Germinal Centers. Annu Rev Immunol (2011) 30:429-57. doi: 10.1146/annurev-immunol-020711-075032

60. Aranburu A, Ceccarelli S, Giorda E, Lasorella R, Ballatore G, Carsetti R. TLR ligation triggers somatic hypermutation in transitional $\mathrm{B}$ cells inducing the generation of IgM memory B cells. J Immunol (2010) 185:7293-301. doi: 10.4049/jimmunol.1002722

61. Capolunghi F, Rosado MM, Sinibaldi M, Aranburu A, Carsetti R. Why do we need IgM memory B cells? Immunol Lett (2013) 152:114-20. doi: 10.1016/ j.imlet.2013.04.007

62. Seow J, Graham C, Merrick B, Acors S, Pickering S, Steel KJA, et al. Longitudinal observation and decline of neutralizing antibody responses in the three months following SARS-CoV-2 infection in humans. Nat Microbiol (2020) 5:1598-607. doi: 10.1038/s41564-020-00813-8

63. Ibarrondo FJ, Fulcher JA, Goodman-Meza D, Elliott J, Hofmann C, Hausner MA, et al. Rapid Decay of Anti-SARS-CoV-2 Antibodies in Persons with Mild Covid-19. N Engl J Med (2020). doi: 10.1056/nejmc2025179

64. Vabret N. Antibody responses to SARS-CoV-2 short-lived. Nat Rev Immunol (2020) 383:e74. doi: 10.1038/s41577-020-0405-3

65. Beaudoin-Bussières G, Laumaea A, Anand SP, Prévost J, Gasser R, Goyette G, et al. Decline of humoral responses against sars-cov-2 spike in convalescent individuals. MBio (2020) 11(5):e0250-20. doi: 10.1128/mBio.02590-20

66. Long QX, Tang XJ, Shi QL, Li Q, Deng HJ, Yuan J, et al. Clinical and immunological assessment of asymptomatic SARS-CoV-2 infections. Nat Med (2020) 26:1200-4. doi: 10.1038/s41591-020-0965-6

67. Rijkers G, Murk J-L, Wintermans B, van Looy B, van den Berge M, Veenemans J, et al. Differences in Antibody Kinetics and Functionality Between Severe and Mild Severe Acute Respiratory Syndrome Coronavirus 2 Infections. J Infect Dis (2020) 222(8):1265-9. doi: 10.1093/infdis/jiaa463

68. Lam VC, Lanier LL. NK cells in host responses to viral infections. Curr Opin Immunol (2017) 44:43-51. doi: 10.1016/j.coi.2016.11.003

69. Vidal SM, Khakoo SI, Biron CA. Natural killer cell responses during viral infections: Flexibility and conditioning of innate immunity by experience. Curr Opin Virol (2011) 1(6):497-512. doi: 10.1016/j.coviro.2011.10.017

70. Abel AM, Yang C, Thakar MS, Malarkannan S. Natural killer cells: Development, maturation, and clinical utilization. Front Immunol (2018) 9:1869. doi: 10.3389/fimmu.2018.01869
71. Ochsenbein AF, Zinkernagel RM. Natural antibodies and complement link innate and acquired immunity. Immunol Today (2000) 21(12):624-30. doi: 10.1016/S0167-5699(00)01754-0

72. Ochsenbein AF, Fehr T, Lutz C, Suter M, Brombacher F, Hengartner H, et al. Control of early viral and bacterial distribution and disease by natural antibodies. Sci (80- ) (1999) 286(5447):2156-9. doi: 10.1126/science.286. 5447.2156

73. McGonagle D, Sharif K, O'Regan A, Bridgewood C. The Role of Cytokines including Interleukin-6 in COVID-19 induced Pneumonia and Macrophage Activation Syndrome-Like Disease. Autoimmun Rev (2020) 19(6):10253730. doi: 10.1016/j.autrev.2020.102537

74. Sanchez-Cerrillo I, Landete P, Aldave B, Sanchez-Alonso S, Sanchez-Azofra A, Marcos-Jimenez A, et al. Differential Redistribution of Activated Monocyte and Dendritic Cell Subsets to the Lung Associates with Severity of COVID-19. medRxiv (2020). doi: 10.1101/2020.05.13.20100925

75. Merad M, Martin JC. Pathological inflammation in patients with COVID19: a key role for monocytes and macrophages. Nat Rev Immunol (2020) 20:355-62. doi: 10.1038/s41577-020-0331-4

76. Moore JB, June $\mathrm{CH}$. Cytokine release syndrome in severe COVID-19. Sci (80- ) (2020) 55(5):105954. doi: 10.1126/science.abb8925

77. Hayden A, Park S, Giustini D, Lee AYY, Chen LYC. Hemophagocytic syndromes (HPSs) including hemophagocytic lymphohistiocytosis (HLH) in adults: A systematic scoping review. Blood Rev (2016) 30(6):411-20. doi: 10.1016/j.blre.2016.05.001

78. Locatelli F, Jordan MB, Allen C, Cesaro S, Rizzari C, Rao A, et al. Emapalumab in Children with Primary Hemophagocytic Lymphohistiocytosis. N Engl J Med (2020) 382:1811-22. doi: 10.1056/nejmoa1911326

79. Prilutskiy A, Kritselis M, Shevtsov A, Yambayev I, Vadlamudi C, Zhao Q, et al. SARS-CoV-2 Infection Associated Hemophagocytic Lymphohistiocytosis: An autopsy series with clinical and laboratory correlation. Am J Clin Pathol (2020) 154(4):466-74. doi: 10.1101/2020.05.07.20094888

80. Zhang S, Li L, Shen A, Chen Y, Qi Z. Rational Use of Tocilizumab in the Treatment of Novel Coronavirus Pneumonia. Clin Drug Invest (2020) 40 (6):511-8. doi: 10.1007/s40261-020-00917-3

81. King A, Vail A, O'Leary C, Hannan C, Brough D, Patel H, et al. Anakinra in COVID-19: important considerations for clinical trials. Lancet Rheumatol (2020) 2(7):379-81. doi: 10.1016/S2665-9913(20)30160-0

82. Madera S, Rapp M, Firth MA, Beilke JN, Lanier LL, Sun JC. Type I IFN promotes NK cell expansion during viral infection by protecting NK cells against fratricide. J Exp Med (2016) 213(2):225-33. doi: 10.1084/ jem. 20150712

83. González-Navajas JM, Lee J, David M, Raz E. Immunomodulatory functions of type i interferons. Nat Rev Immunol (2012) 12(2):125-35. doi: 10.1038/ nri3133

84. Blanco-Melo D, Nilsson-Payant BE, Liu WC, Uhl S, Hoagland D, Møller R, et al. Imbalanced Host Response to SARS-CoV-2 Drives Development of COVID-19. Cell (2020) 181(5):1036-45. doi: 10.1016/j.cell.2020.04.026

85. Hung IF-N, Lung K-C, Tso EY-K, Liu R, Chung TW-H, Chu M-Y, et al. Triple combination of interferon beta-1b, lopinavir-ritonavir, and ribavirin in the treatment of patients admitted to hospital with COVID-19: an open-label, randomised, phase 2 trial. Lancet (2020) 395(10238):1695-704. doi: 10.1016/ s0140-6736(20)31042-4

86. Zhang Q, Bastard P, Liu Z, Le Pen J, Moncada-Velez M, Chen J, et al. Inborn errors of type I IFN immunity in patients with life-threatening COVID-19. Sci (80- ) (2020) 370(6515):eabd4570. doi: 10.1126/science.abd4570

87. Bastard P, Rosen LB, Zhang Q, Michailidis E, Hoffmann H-H, Zhang Y, et al. Auto-antibodies against type I IFNs in patients with life-threatening COVID-19. Sci (80- ) (2020) 370(6515):eabd4585. doi: 10.1126/science.abd4585

88. Guo L, Ren L, Yang S, Xiao M, Chang D, Yang F, et al. Profiling Early Humoral Response to Diagnose Novel Coronavirus Disease (COVID-19). Clin Infect Dis (2020) 71(15):778-85. doi: 10.1093/cid/ciaa310

89. Nielsen SCA, Yang F, Jackson KJL, Hoh RA, Röltgen K, Jean GH, et al. Human B Cell Clonal Expansion and Convergent Antibody Responses to SARS-CoV-2. Cell Host Microbe (2020) 28(4):516-25. doi: 10.1016/ j.chom.2020.09.002

90. Andreano E, Nicastri E, Paciello I, Pileri P, Manganaro N, Piccini G, et al. Identification of neutralizing human monoclonal antibodies from Italian Covid-19 convalescent patients. bioRxiv (2020). doi: 10.1101/2020.05.05.078154 
91. Huang KJ, Su IJ, Theron M, Wu YC, Lai SK, Liu CC, et al. An interferon- $\gamma-$ related cytokine storm in SARS patients. J Med Virol (2005) 75(2):185-94. doi: 10.1002/jmv.20255

92. He L, Ding Y, Zhang Q, Che X, He Y, Shen H, et al. Expression of elevated levels of pro-inflammatory cytokines in SARS-CoV-infected ACE2+ cells in SARS patients: Relation to the acute lung injury and pathogenesis of SARS. J Pathol (2006) 210(3):288-97. doi: 10.1002/path.2067

93. Stavnezer J, Kang J. The Surprising Discovery That TGF $\beta$ Specifically Induces the IgA Class Switch. J Immunol (2009) 182(1):5-7. doi: 10.4049/ jimmunol.182.1.5

94. Chen W. A potential treatment of COVID-19 with TGF- $\beta$ blockade. Int $J$ Biol Sci (2020) 16(11):1954-5. doi: 10.7150/ijbs.46891

95. Ferner RE, Aronson JK. Remdesivir in covid-19. BMJ (2020) 369:m1610. doi: 10.1136/bmj.m1610

96. Capolunghi F, Cascioli S, Giorda E, Rosado MM, Plebani A, Auriti C, et al. CpG drives human transitional $\mathrm{B}$ cells to terminal differentiation and production of natural antibodies. J Immunol (2008) 180:800-8. doi: 10.4049/jimmunol.180.2.800

97. Grimsholm O, Piano Mortari E, Davydov AN, Shugay M, Obraztsova AS, Bocci C, et al. The Interplay between CD27dull and CD27bright B Cells Ensures the Flexibility, Stability, and Resilience of Human B Cell Memory. Cell Rep (2020) 30(9):2963-77. doi: 10.1016/j.celrep.2020.02.022

98. Carsetti R, Di Sabatino A, Rosado MM, Cascioli S, Piano Mortari E, Milito C, et al. Lack of Gut Secretory Immunoglobulin A in Memory B-Cell Dysfunction-Associated Disorders: A Possible Gut-Spleen Axis. Front Immunol (2020) 10:2937. doi: 10.3389/fimmu.2019.02937

99. Rosado MM, Aranburu A, Capolunghi F, Giorda E, Cascioli S, Cenci F, et al. From the fetal liver to spleen and gut: the highway to natural antibody. Mucosal Immunol (2009) 2:351-61. doi: 10.1038/mi.2009.15

100. Holodick NE, Rodríguez-Zhurbenko N, Hernández AM. Defining Natural Antibodies. Front Immunol (2017) 8:872. doi: 10.3389/fimmu.2017.00872

101. Throsby M, van den Brink E, Jongeneelen M, Poon LLM, Alard P, Cornelissen $\mathrm{L}$, et al. Heterosubtypic neutralizing monoclonal antibodies cross-protective against $\mathrm{H} 5 \mathrm{~N} 1$ and $\mathrm{H} 1 \mathrm{~N} 1$ recovered from human IgM+ memory B cells. PloS One (2008) 3(12):e3942. doi: 10.1371/journal.pone.0003942

102. Carsetti R, Quintarelli C, Quinti I, Piano Mortari E, Zumla A, Ippolito G, et al. The immune system of children: the key to understanding SARS-CoV-2 susceptibility? Lancet Child Adolesc Heal (2020) 4:414-6. doi: 10.1016/ S2352-4642(20)30135-8

103. Selva KJ, van de Sandt CE, Lemke MM, Lee CY, Shoffner SK, Chua BY, et al. Distinct systems serology features in children, elderly and COVID patients. medRxiv (2020). doi: 10.1101/2020.05.11.20098459

104. Seydoux E, Homad LJ, MacCamy AJ, Parks KR, Hurlburt NK, Jennewein $\mathrm{MF}$, et al. Analysis of a SARS-CoV-2 infected individual reveals development of potent neutralizing antibodies to distinct epitopes with limited somatic mutation. Immunity (2020) 53(1):98-105. doi: 10.1016/ j.immuni.2020.06.001

105. Doherty PC, Topham DJ, Tripp RA, Cardin RD, Brooks JW, Stevenson PG. Effector CD4+ and CD8+ T-cell mechanisms in the control of respiratory virus infections. Immunol Rev (1997) 159:105-17. doi: 10.1111/j.1600065X.1997.tb01010.x

106. McLane LM, Abdel-Hakeem MS, Wherry EJ. CD8 T Cell Exhaustion During Chronic Viral Infection and Cancer. Annu Rev Immunol (2019) 37:457-95. doi: 10.1146/annurev-immunol-041015-055318

107. Pavlovich SS, Lovett SP, Koroleva G, Guito JC, Arnold CE, Nagle ER, et al. The Egyptian Rousette Genome Reveals Unexpected Features of Bat Antiviral Immunity. Cell (2018) 173(5):1098-110. doi: 10.1016/ j.cell.2018.03.070

108. Baker ML, Tachedjian M, Wang LF. Immunoglobulin heavy chain diversity in Pteropid bats: Evidence for a diverse and highly specific antigen binding repertoire. Immunogenetics (2010) 62:173-84. doi: 10.1007/s00251-0100425-4

109. Banerjee A, Baker ML, Kulcsar K, Misra V, Plowright R, Mossman K. Novel Insights Into Immune Systems of Bats. Front Immunol (2020) 11:26. doi: $10.3389 /$ fimmu.2020.00026

110. Liu J, Li S, Liu J, Liang B, Wang X, Wang H, et al. Longitudinal characteristics of lymphocyte responses and cytokine profiles in the peripheral blood of SARS-CoV-2 infected patients. EBioMedicine (2020) 55:102763. doi: 10.1016/j.ebiom.2020.102763

111. Chen m, Tu c, Tan C, Zheng X, xiaohua W, Wu j, et al. Key to successful treatment of COVID-19: accurate identification of severe risks and early intervention of disease progression. medRxiv (2020). doi: 10.1101/ 2020.04.06.20054890

Conflict of Interest: The authors declare that the research was conducted in the absence of any commercial or financial relationships that could be construed as a potential conflict of interest.

Copyright (c) 2020 Carsetti, Zaffina, Piano Mortari, Terreri, Corrente, Capponi, Palomba, Mirabella, Cascioli, Palange, Cuccaro, Milito, Zumla, Maeurer, Camisa, Vinci, Santoro, Cimini, Marchioni, Nicastri, Palmieri, Agrati, Ippolito, Porzio, Concato, Onetti Muda, Raponi, Quintarelli, Quinti and Locatelli. This is an openaccess article distributed under the terms of the Creative Commons Attribution License (CC BY). The use, distribution or reproduction in other forums is permitted, provided the original author(s) and the copyright owner(s) are credited and that the original publication in this journal is cited, in accordance with accepted academic practice. No use, distribution or reproduction is permitted which does not comply with these terms. 